
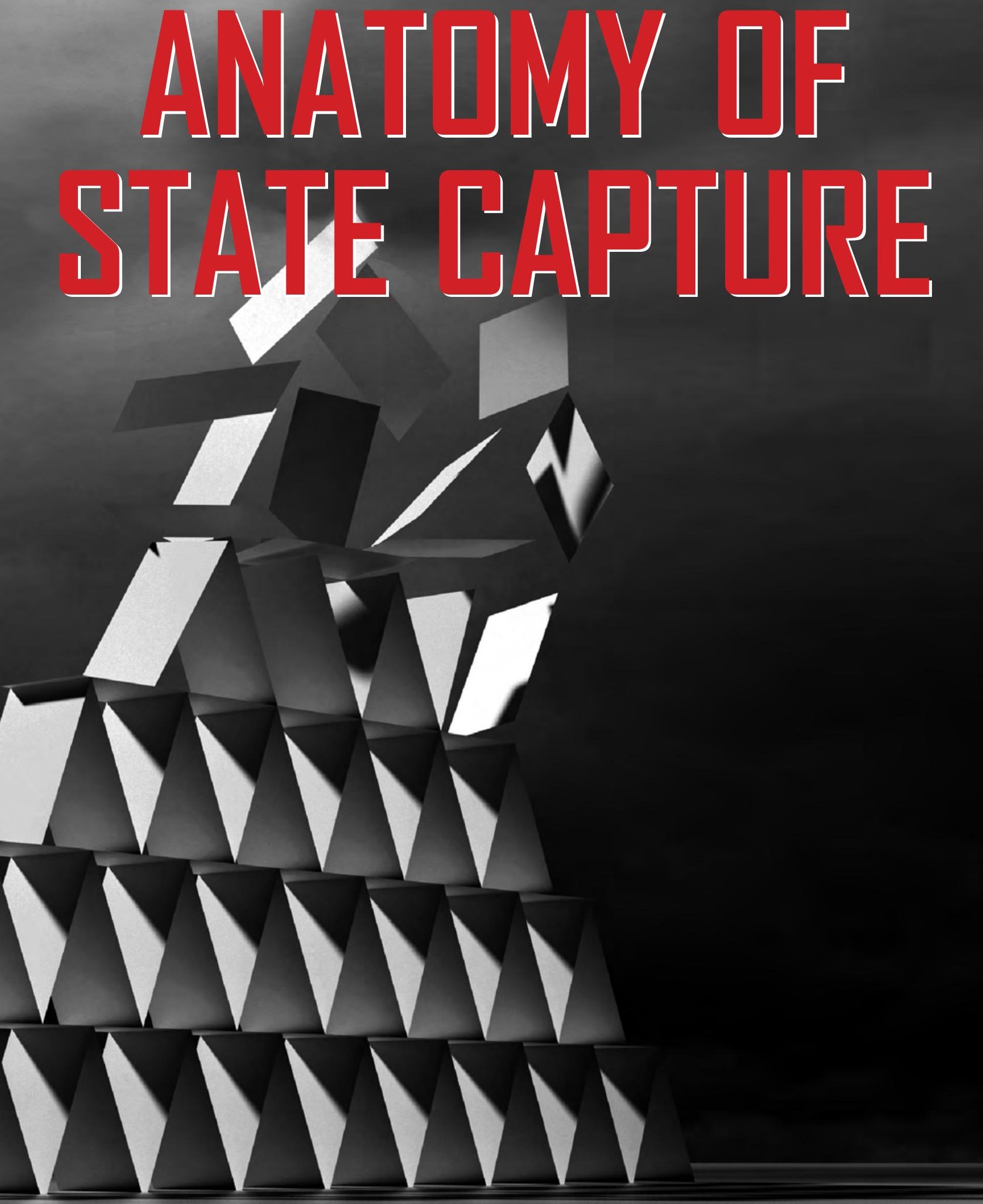

Nina Callaghan, Rabyn Foley and Mark Swilling (EDITuRS) 


\section{STATE CAPTURE AT DENEL}

Nina Callaghan

\subsection{INTRODUCTION}

The machinery of war is a lucrative business, it is also a shadowy one in South Africa's history of arms dealing. Highly classified information, secret deals, shady middlemen and a highly concentrated, centralised power structure - this is the nature of arms dealing past and present. All these elements, we argue, make an institution vulnerable to capture.

South Africa develops and sells arms through Denel, a state-owned company that in 1992 emerged out of its apartheid predecessor, Armaments Corporation of South Africa (Armscor) (Cock \& Mckenzie, 1998). Central to the capture of state and a recurrent theme throughout this book, is the repurposing of state institutions to funnel finance and influence away from the developmental project towards a sophisticated network of a power elite (Bhorat, Buthelezi, Chipkin, Duma, Mondi, Peter, Qobo, Swilling \& Friedenstein, 2017). This case study locates Denel in the history of South Africa, first as a key prop for the apartheid project (Batchelor \& Willet, 1998) and then for the racket of state capture during Jacob Zuma's presidency from 2013 through to 2018 .

This chapter will look at Denel as an historical entity and suggests that it has always been captured, first, because of the nature of the armament business and second as a vehicle for select development for both an apartheid regime and a democratic government. In both cases, SOEs played a key role in generating business for the state. For apartheid South Africa, the defence prowess was a means to develop white domination and privilege (Hart \& Padayachee, 2013), and shows Denel as a central $\operatorname{cog}$ in the apartheid regime. This chapter touches on the dealings between the state and sanctions busters at the time to illustrate the point that corrupt networks and extractive ways of doing business are not a new phenomenon. This point is further emphasised by Denel's involvement in the Arms Deal of 1999. During the Zuma-era, procurement spend at SOEs was used as a way to extract rents under the hijacked ideology of radical economic transformation. This chapter looks at the corporate and 
political manoeuvrings of capture actors to eventually decimate governance at Denel and rob the public purse.

The trajectory shows that Denel's successive fates have always been tainted by corruption and that the Guptas and their associates were just the latest in an opportunistic and parasitic network that has historically surrounded the company. The nature of the armament industry and its relationship to the apparatus of state capture is summed up well in the following quote and points to how state capture was able to pull off its grand looting:

... once an arms industry is established it is not a neutral agent in the economy. It often spreads new production processes and standards, encourages Research \& Development intensive activities, and favours particular management practices. Combined, these factors contribute to the creation of a new technological paradigm and culture embodied in the defence industry but which operates in the larger institutional and social context. (Batchelor \& Willet, 1998)

\subsection{ARMSCOR DURING APARTHEID}

The apartheid regime in South Africa (1946-1994) was a highly militarised institution. Its weaponised command and control culture was designed with the specific intent of enforcing and maintaining minority white power through racial oppression and systematic violence against the majority blacks. Militarism can be understood as the apartheid state's culture - aligned with its local and regional military goals, values and apparatus (Batchelor and Willet, 1998).

During the regime, South Africa was one of the few developing countries in the world that took on the economic burden of developing its own arms industry, alongside a space and nuclear weapons programme (Henk, 2004). From 1948 when the Nationalist Government came to power, until 1989, apartheid nurtured a military might and expertise that was singular on the continent (Batchelor \& Willet, 1998; Henk, 2004). It is suggested that the multiple arms embargos imposed by the UN between 1970 and 1977, along with other international boycotts, fuelled the Nationalist Party's (NP) rhetoric of a "total onslaught" against white South Africa (Wessels, 2010). This in turn, Wessels argues, strengthened the regime's support from an all-white electorate, along with resurgent support for South Africa's cross border wars in Angola, Namibia and Mozambique.

The mandatory UN arms embargo of 1977 was enforced because the Security Council considered South Africa a threat to international peace and security. Its decision considered the violent enforcement of apartheid domestically, South Africa's military build-up and acts of war against its neighbours and its nuclear development 
programme (Wessels, 2010). The embargo banned all arms exports, ammunition, armaments supplies and licensing agreements to reproduce arms equipment, as well as any support for the country's nuclear programme. The result was that South Africa took on the development of its defence sector with renewed vigor (Batchelor \& Willet, 1998; Henk, 2004).

Through Armscor, an entity that was part of the Department of Defence, the country was able to meet all domestic and regional military objectives, and make a roaring legal and illicit international profit through arms dealing (Cock \& Mckenzie, 1998; Van Vuuren, 2017).

By the end of the era, 3,000 private sector enterprises serviced some aspect of the industry as contractors, subcontractors or suppliers. Arms producers accounted for fully $9 \%$ of the country's employment in manufacturing. Arms comprised $6.6 \%$ of all South African manufacturing output and $1.5 \%$ of the country's gross domestic product. (Henk, 2004, p. 14)

Up until 1989, the apartheid Defence Force formed the nexus from which governance radiated into all other aspects of South African life, as well as directing engagements with the private sector (Batchelor \& Willet, 1998). These private sector actors, both local and international, were intent on putting profit and political interest before the well-being of the majority of South Africans (Van Vuuren, 2017) with many calls for them now to be held to account. Amongst the businesses and countries accused of profiteering from apartheid are 196 banks across 27 countries, the main one being Kredietbank in Belgium. The French arms company Thompson CF, now known as Thales, and implicated in the 1999 Arms Deal, was also a major player, as well as all five permanent members of the UN Security Council - UK, USA, China, Soviet Union and France, the latter became the kingpin in Armscor's arms dealing (Van Vuuren, 2017).

\subsection{DEMILITARISATION, DEMOCRACY AND THE FORMATION OF DENEL}

1989 marked a turning point in South Africa's political trajectory. It was the year the war of independence ended in Namibia and the South African army withdrew in defeat. In the build-up to democracy, the defence sector was restructured, the defence budget reduced by $40 \%$ and procurement by $60 \%$ between 1989 and 1993 (Henk, 2004). During the same time, employment in the defence industry was almost halved to just over 70000 jobs while investment in defence research and development as a proportion of the country's total, fell from $48 \%$ to $18 \%$ (Henk, 2004). In the transition from apartheid to democracy, the parastatal Armscor transitioned into Denel in 1992, but many critics say the power structures of the apartheid entity remained. Denel 
inherited Armscor's research and development, production facilities and about 1500 workers (Batchelor \& Willet, 1998). Denel also inherited all Armscor's networks, institutional culture and a corrupt culture of doing business (Van Vuuren, 2017).

\subsubsection{Denel's Performance 1994-2001}

The transition to democracy was a financial blow to Denel. The company's 2007 annual report summary illustrates this drastic downward trend between 1996-1999. Profits dropped from R400m to a staggering R800m in the red. The entire local defence industry was in a fair scramble during this time, with mergers and acquisitions the response to a shrinking local and international market (Dunne \& Haines, 2002). Like other defence companies, Denel attempted to consolidate its position in the market, and did away with most outsourcing, preferring to vertically integrate all goods and services. Not only was this an expensive exercise, it also resulted in increased concentration in the defence sector (Dunne \& Haines, 2002).

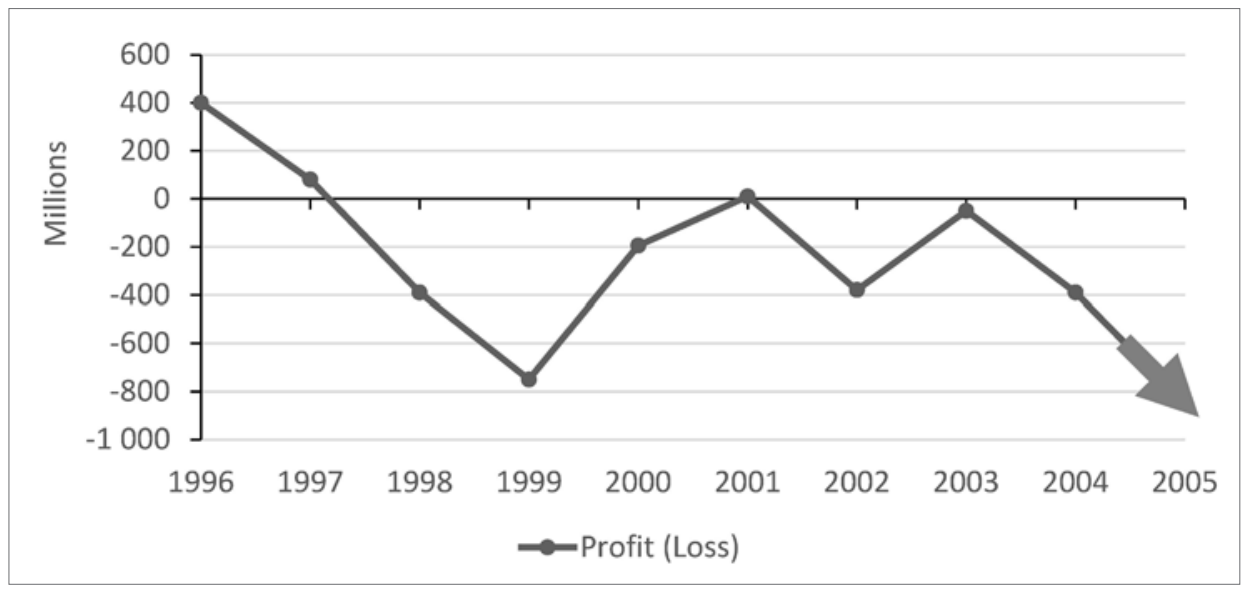

FIGURE 8.1 Denel Financial Indicators: 1996-2005

Source: Denel (2007) annual report summary presentation

A dramatic spike over the next two years, 1999-2001, allowed Denel to at least break even. Then acting CEO, Flip Botha, attributed the recovery to a much improved export market with foreign orders making up 46\% of total sales in 2001 (Leuvennink, 2001). In 2000, Cabinet approved plans for UK arms giant, BAE Systems, and Swiss $\mathrm{SAAB}$ to become equity partners in Denel Aviation. But these deals were not just the result of a miraculous recovery in a shrinking global defence market, as Denel's annual reports and sterile financial reporting present. Rather, it must be seen in relation to the Strategic Arms Package, more commonly known as the Arms Deal of 1999 (Sylvester \& Seegers, 2011). At first, the deal was pegged at R30bn for the acquisition of sophisticated defence equipment. Fighter jets, warships, submarines 
and helicopters made up the package that has eventually cost an estimated R65bn to date with payments scheduled up until 2022 (Davis \& Mutemwa-Tumbo, 2019). The Seriti Inquiry was established in 2011 at the behest of former President Zuma to probe allegations of corruption. General Bayne and General Malinga of the South African Airforce (SAAF) testified at the commission that the Defence Force did indeed have a pressing need to replace an aging jet and helicopter fleet or it would face obsolescence (Arms Procurement Commission, 2016, p. 623). This testimony is in contradiction to critics who insist the country had no need for an arms upgrade. It must also be noted that the Seriti findings have since been set aside; the Pretoria High Court ruled that the commission failed to properly investigate the Arms Deal (High Court of South Africa: North Gauteng, 2019).

\subsubsection{Denel and the Arms Deal}

The arms deal was beset by accusations of bribery and corruption. Chief amongst the alleged benefactors of kickbacks and bribes from the Arms Deal was Fana Hlongwane, a special advisor to then Defence Minister, Joe Modise. Hlongwane later became a Board Member of Denel. Also allegedly profiting from the deal was Major-General Ian Deetlefs, former Board Member of Denel who later became CEO (Corruption Watch, 2018). Former President Jacob Zuma is also implicated in the ill-gotten gains of the Arms Deal, being charged with misuse of power and improper influence. These charges were dismissed in 2009 but reinstated by the NPA in April 2018, just weeks after Zuma was recalled from the Presidency. Zuma's financial advisor, Shabir Shaik, was said to have arranged an annual R500 000 payment for Zuma from Thompson-CSF, now Thales, one of the arms companies involved in the deal (Corruption Watch, 2018).

While there were fixers, middlemen and a host of support players it was the spin-offs from the arms deal that created a local feeding frenzy. These opportunities for rent seeking were generated from offset agreements, which were incentives used by arms companies to sweeten the deal for buyers and were often referred to as industrial participation programmes'. It was exactly these kinds programmes that made the investments of BAE and SAAB, mentioned earlier, possible (Sylvester \& Seegers, 2011). The Arms Deal created a wealth of opportunities for Denel to sign strategic partnership agreements with foreign arms traders which was supposed to add investment capital, increase procurement spend, support research and development and capacity building for Denel. The financial benefits from the arms deal spin-offs for Denel were pegged at R2.5bn over 10 years (Leuvennink, 2001) with Denel and its subsidiaries producing components for the procured arms. Then Defence Minister Joe Modise (1999) hailed the deal as a development boon for South Africa: 
Reequipping the Defence Force ... will benefit our economy by an estimated R110 billion of new investment and industrial participation programmes, and creation of approximately 65000 jobs. As to concerns that such transactions are open to improper influences, I want to assure you that the bids have gone through a fine-tooth comb to ensure an ethical outcome.

It can be concluded that the biggest corruption scandal to hit South Africa five years into democracy was what greased the wheels for Denel's recovery during this short time, 1990-2001. It also lined the pockets of at least two known major players in Denel's governance structures. Not only did the corrupt deal come under immense political pressure from civil society, but the promised benefits also fizzled away due to Denel's failure to deliver on the contracts. Instead of lining the national purse, Denel became a drain on taxpayers who had to foot a bill of over R660m to help the failing company make good on its arms deal obligations (Ensor, 2008).

Former ANC MP and robust critic of the arms deal, Andrew Feinstein, describes the Strategic Arms Package as the first documented case of state capture (Mitchley, 2019). In many ways the structural plot of the arms deal mirrors how corruption became syndicated in the state capture project. In both instances opportunities to secure rents were identified, the Executive was seduced by potential development interests through state procurement with the private sector, which never materialised. In both cases, deal makers and middlemen negotiated between the state and the private sector, pocketing bribes and fixer fees as they went. Networks were central to enacting this level of systemic corruption. In both cases, multiple levels of state governance and oversight bodies either knew about corrupt activities and turned a blind eye, or actively facilitated corrupt transactions and relationships. In both cases, there was a bending of the rules or a flagrant disregard for them as well as public sentiment. In both cases, a huge amount of public money was used for narrow interests with nobody held to account or prosecuted - yet.

\subsubsection{Tall Tasks for Denel Boards}

The Board Members of SOEs are appointed by the arch governing body, the Department of Public Enterprises. It is the Minister who appoints the Board and oversees the mandate of that entity. Beset with falling profits since 2003, former Denel Board member, Talib Sadik, was appointed as CEO in late 2008, assigned as a key driver of the SOEs turnaround strategy. By the time Sadik left in 2011, Denel was back to making a marginal profit.

Riaz Saloojee was appointed as CEO in 2011 when Malusi Gigaba was Public Enterprise Minister. Saloojee had extensive experience in the defence and manufacturing sectors, was a former member of the SANDF and headed up other armaments 
companies in the past. Under both Sadik and Saloojee, the Boards were constituted of highly professional people. They were recruited for their specialist skills in finance, defence, legal, industrial and labour relations, engineering, management and governance (Denel, 2011). This defining feature of Board expertise would come to be eroded during the most intensive state capture period starting in 2015, where Board appointees were described as ill-equipped to oversee an SOE with industry-specific needs (Janse van Rensburg, 2019).

Table 8.1 illustrates finance results between 2007 and 2018 and tells us that Denel incurred huge operational costs with short periods of marginal revenue. What is perhaps most noteworthy is the massive loss of R1.7bn Denel suffered in 2018. At the same time, rating agency Fitch also downgraded the company, impacting its ability to attract future funding. This was the culmination of three years of poor governance due to a weak Board, systemic corruption linked to state capture actors like the Guptas and their associates and the low confidence trade and financial partners had in Denel during the most intensive period of state capture.

TABLE 8.1 Denel Profit/Loss Summary over time

\begin{tabular}{|c|c|c|c|c|c|c|c|c|c|c|c|c|}
\hline Year & '18 & '17 & '16 & '15 & $' 14$ & '13 & '12 & '11 & '10 & '09 & '08 & '07 \\
\hline \multicolumn{13}{|c|}{ Rand in Millions } \\
\hline Revenue & 4998 & 8057 & 8228 & 5852 & 4588 & 3918 & 3568 & 3252 & 3610 & 3924 & 3818 & 3268 \\
\hline $\begin{array}{l}\text { Operating } \\
\text { expenses }\end{array}$ & (1726) & (1483) & $(1455)$ & (939) & $(879)$ & $(940)$ & $(958)$ & (897) & (846) & (1285) & (1082) & (1257) \\
\hline $\begin{array}{l}\text { Profit/(Loss) } \\
\text { for year }\end{array}$ & (1758) & 333 & 395 & 270 & 194 & 71 & 41 & 111 & (246) & $(533)$ & (347) & $(549)$ \\
\hline
\end{tabular}

Source: Denel Financials 2007-2018

The image and reputation of Denel, as well as the credibility of its leadership has since 2015 been on a downward spiral within the stakeholder environment, the broader South African public, as well as in both local and international markets. This has had crippling impacts on not only the internal employee environment, the external supplier, customer and industry environments, but also in the banking and financial sectors. (Denel, 2018, p. 36)

It is noteworthy that the annual report states that its leadership and governance trouble started in 2015. This was when a new Board was appointed, when CEO Saloojee was fired, along with the Company Secretary, Elizabeth Africa and the CFO, Fikile Mhlontlo, which is explained in more detail later in the chapter.

\subsection{ARRANGING DENEL'S CAPTURE}

Forensic investigations into state capture in South Africa by the media and researchers in academia tell us that it takes multiple institutions, multiple players at all levels 
and from all sectors to infiltrate and then repurpose a system for looting (Bhorat, Buthelezi, Chipkin, Duma, Mondi, Peter, Qobo, Swilling \& Friedenstein, 2017). In the case of SOEs, there were particular 'tools' used to facilitate this racket, like compliant Boards, hiring and firing of people in key government positions, powerful corporate appointees, fixers and corporate partners to mention some of them. The case of the capture of Denel was no different.

The Board serving together with the leadership of CEO Saloojee came to the end of its term in July 2015. This was when members could be rotated off the forum and new members appointed by the Minister. A report that evaluated Board effectiveness was concluded by accounting firm, Deloitte \& Touche in June 2015 and was submitted to the Zondo Commission by former Denel Board Chair, Martie Janse van Rensburg, as part of her statement (Janse van Rensburg, 2019). The report formed part of a standard annual process of observing good governance. The evaluation was complementary of the outgoing Board chaired by Janse van Rensburg, saying, "The Denel Board is consider [sic] to be highly effective both in providing the necessary oversight as well as direction to Denel. This has been confirmed and corroborated through the Board Effectiveness Evaluation" (Janse van Rensburg, 2019, p. 35).

In compiling the report, Deloitte was privy to the Board succession plans proposed by the new Minister of Public Enterprises, Lynn Brown, who took office in 2014. Her plan was to replace everyone on the Board, except one member. This was irregular according to the report, which recommended standard practice of retaining at least a third of the membership for purposes of continuity and momentum, especially for a company engaged in a turnaround strategy. The report advised against Brown's plan, "The succession of the Board as a whole as well as the Chairman was noted as an area of significant concern ..." (Janse van Rensburg, 2019, p. 36).

Brown's own department compiled a list of candidates for the incoming Board, also advising she retain most members for their good performance and because many had not yet served their maximum two terms (PARI, 2018). It was against the advice from these quarters that Brown made the decision to replace the entire Board with candidates who lacked experience of Corporate Board Membership and the requisite skills needed for a technical company like Denel (amaBhungane, 2017). One Board Member was retained, Johannes Motseki, who enjoyed a close relationship with Zuma's son, Duduzane Zuma, and has been linked to the Guptas through a business partnership in the family's Oakbay Investments (Letsoalo, Faull \& Mataboge, 2011; PARI, 2018).

Brown appointed Daniel Mantsha as Chair of the Board and Non-Executive Director, a discredited lawyer who was struck off the roll in 2007 after complaints from clients 
that he was dishonest (Hunter, 2018). Mantsha was readmitted as an attorney in 2011, and in 2015 became advisor to former Communications Minister and current Chair of the Justice Portfolio Committee in Parliament, Faith Muthambi. Following his Board appointment, \#GuptaLeaks emails shows Mantsha on Gupta-sponsored trips to India and Dubai, and that he allegedly forwarded an outstanding municipal account to a Gupta associate, Ashu Chawla (Hunter, 2018). Mantsha is a key actor in facilitating the capture of Denel. Saloojee accused Mantsha of manufacturing a case against him and the company secretary to get them fired and pave the way to facilitate the Denel Asia deal (Saloojee, 2019, para. 45). Further, it is Mantsha who allegedly shared confidential company information with the Guptas, giving the family a competitive advantage in exchange for favours (amaBhungane, 2017).

Another Denel Board appointee linked to the Guptas was Thamsanqa Msomi, former Chief of Staff to former Public Enterprise Minister Malusi Gigaba. Msomi later served as his legal advisor when Gigaba was Home Affairs Minister. It is alleged through \#GuptaLeaks emails that Msomi received and acted on requests from Gupta associate Chawla for assistance with visas for Gupta clients and employees. Details of Msomi's alleged fixing was heard at the Zondo Commission and the Gupta Naturalisation Parliamentary Inquiry in 2018, and remain allegations in the face of no cross examination (Hunter \& Cowan, 2017; PMG, 2018).

Following the exodus of the former Board in July 2015, the top officers of Denel were next to go. One of Mantsha's first tasks just two months after taking the Chair was to suspend CEO Riaz Saloojee, CFO Fikile Mhlontlo and Company Secretary, Elizabeth Africa, allegedly for irregularities over a huge contract with BAE Land Systems. This happened despite the outgoing Board making sure to ratify the deal with all processes and motivations expressly communicated. The allegations against the three were later found to be spurious, even so, Saloojee was officially fired in April 2016 and his two colleagues never reinstated.

Testifying at the Zondo Commission, Saloojee mentions meeting the Guptas three times, the first as early as 2012. He details how the meetings were facilitated by Salim Essa, a Gupta associate who made sure Saloojee knew that doing business with the Guptas had "support from the top" (Saloojee, 2019, p. 45). In his statement to the Commission, Saloojee places then Public Enterprise Minister Gigaba at the Guptas' home, saying, "These people are friends' and that he hoped that we could work together in the future" (Saloojee, 2019, p. 45).

On other occasions, Saloojee alleges Zuma's son, Duduzane, was present at the Gupta residence along with Ace Magashule's son. Saloojee describes these as business prospecting meetings as well as displaying the Guptas' links to political power. Saloojee says 
over the course of the meetings and subsequent communications, he reiterated that the Guptas engage through the proper business channels to pursue their interests in defence markets in the Middle East and Asia. Saloojee was evidently not taking the bait, which was eventually met with coercion at his last meeting at the Gupta compound.

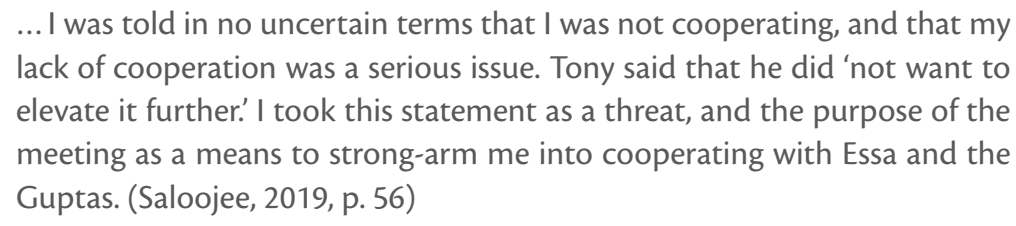

At the last meeting, Saloojee notes how Tony Gupta allegedly made direct reference to bribes, "When the meeting ended, as we walked out, Tony asked me why I don't take money and that I should 'take money because everyone does'. I categorically stated that I do not" (Saloojee, 2019, p. 62).

In the cast of SOE officials approached by the Gupta family, Saloojee turned out to be an obstacle to their plans. Saloojee's suspension and eventual axing comes as no surprise then as we begin to see the capture actors taking hold in Denel. The departure of the previous Board and the top officers smoothed the way for a deal they did not approve of, the formation of Denel Asia which has come to illustrate state capture at Denel.

\subsubsection{Securing Business: India Market Prospects}

India is one of the biggest arms importers in the world and had been a lucrative trading partner in the early 2000s. During that time, Denel had been contracted to supply rifles and rounds of ammunition, G6 self-propelled howitzers (a kind of artillery weapon) and there was also a pending contract to build an ammunition factory in India. India accused Denel of using and paying a "middle man" to secure the $\mathrm{R} 24 \mathrm{~m}$ deal, a procurement practice that is illegal in India for defence contracts (Pressly, 2005).

According to news reports in 2005 (Pressly, 2005), Denel admitted that it used Britishbased Varas Associates to provide technical assistance on the deal. India's Central Bureau of Investigation (CBI) says Denel's $12.75 \%$ payment to Varas was a kickback for their consultants exerting influence on the Indian Defence Ministry to choose Denel as the preferred supplier. The CBI also accused Varas of obtaining pricing information, something Denel denies. The CBI filed a case of corruption against Denel in June 2005, which effectively cancelled all contracts. India then instituted a ban on Denel, preventing it from doing any future business until the sanction was lifted. 
Eight years later, India's CBI closed the investigations and the case of corruption against Denel without being able to substantiate its allegations of corruption. This meant that the potential to do business with India was again an opportunity that was not missed by Denel.

The investigation found that there was in fact no illegal or untoward activities that had been conducted by Denel in India. We welcome the removal of the blacklisting because doing business with India again will further strengthen the relationship South Africa enjoys with the country within the context of the BRICS even more. (Qinga in Martin, 2014)

\subsubsection{Corporate Arrangements}

There are a few criteria that qualify a private business to do deals with a SOE in South Africa. One of them is the BEE rating of that business. In 2008, black businessman Benny Jiyane purchased a $25.1 \%$ stake in VR Laser, a company that cut and moulded steel for armoured and heavy vehicles. The R270m BEE deal qualified VR Laser for government tender contracts, and they appeared to be in no short supply. Amongst the lucrative state contracts were the supplying of steel to Transnet Freight Rail for manufacturing locomotives, providing components for armoured vehicles made by Denel, as well as a potential contract to provide components for Eskom's rebuild programme (PARI, 2018).

Things went horribly sour between VR Laser and Jiyane because of a Gupta-linked company acquiring shares in VR Laser. In March 2019, Jiyane appeared before the Zondo Commission as part of the investigations into state capture. He shared at length how the relationship with Gupta associates resulted in him being pushed out of VR Laser.

Jiyane explained how two of his business partners at VR Laser were set to sell their $74.9 \%$ shares. This prompted him to search for financiers to buy them out for $\mathrm{R} 120 \mathrm{~m}$. Considering the high tech and specialist nature of the contract, Jiyane was adamant that the buyers be South African. It was then that Jiyane met South African businessman Salim Essa at a defence exhibition in Abu Dhabi in 2013 with a view to do business. Essa has been called a "Gupta kingpin", "Gupta associate", "Gupta lieutenant" and "state capture mastermind" in media reports in South Africa for the facilitating role he played in securing deals for the Gupta family (amaBhungane, 2017; Bezuidenhout, 2019).

Essa and Jiyane eventually signed a deal in December 2013, with Essa's company, Elgasolve, acquiring a majority share of VR Laser. When Gupta associates then moved in on VR Laser's operations and ousted Jiyane as CEO, it became clear his continued involvement with the company would be untenable. Jiyane sold his shares at a loss 
for $\mathrm{R} 16 \mathrm{~m}$, at least $\mathrm{R} 8 \mathrm{~m}$ lower than the share sale price of previous buyouts. The deal was facilitated by Craysure Investments, which belonged to Tony Gupta and Duduzane Zuma, former President Jacob Zuma's son. The Gupta link to VR Laser also becomes clearer when Khamal Singhala, son of Ajay Gupta, became a director at VR Laser. Testifying at the Zondo Commission, Jiyane says he only later realised that Essa acted on behalf of the Guptas and that Elgasolve was actually a front company to further the Guptas' interests.

I cannot tell you what my reaction would have been if we had found out that we were dealing with the Gupta family and that Sharma and Essa were just proxies for them ... I had spent years developing and growing VRLS and wanted to continue growing it. I had not intended to sell our shares and only did so after I realised the deception we had fallen prey to. (Jiyane, 2019, p. 63)

Elgasolve's acquisition of VR laser shows how transformation agendas got seriously twisted. Jiyane's principles to enter into business with South Africans and not foreign business in the interest of retaining technical expertise and skills that were not common in South Africa, got him pushed out as lead BEE shareholder. Black business lost to corruption for private gain, executed by another black business.

The acquisition of VR Laser by the Gupta company Elgasolve is a crucial step in the capture of Denel. It sets up the corporate legitimacy to facilitate a much larger deal that involves the formation of Denel Asia, that capitalised on the timing of the opening of the India defence market and Denel's history of doing big international deals.

\subsubsection{Denel Asia}

Driven by the Denel and VR Laser partnership, the plan was to set up Denel Asia which would have close proximity to the burgeoning Asia-Pacific defence markets. Denel punted the ambitious deal as a sure win and part of its strategy to grow its international footprint. Denel Asia would be established in Hong Kong through a partnership with Denel owning 51\% and VR Laser Asia 49\%. VR Laser Asia was described as a shell company, being a subsidiary of VR Laser, but having no assets, no manufacturing capacity and no history of doing business in the region. Denel explained the decision to partner with VR Laser in the following way:

Four potential partners were considered before a decision was taken to select VR Laser Asia based on the company's experience and track record of VR Laser working with Denel. VR Laser Asia is wholly-owned by Mr Salim Essa and the company is familiar with the industrial landscape in the world's fastest growing defence market, specifically in India. (Denel, 2016)

According to amaBhungane's cache of leaked emails called \#GuptaLeaks, the family was establishing another tier to the business, to form Denel India. This second entity 
was the one that would actually transact with India. Denel's share in Denel India was reduced to $25 \%$ with the Guptas controlling a $42 \%$ share. The Guptas brought highlevel political connections to the table, their associates linked all the way to Narendra Modi, the Indian Prime Minister (amaBhungane, 2017). The structure of the deal meant that Denel would be selling off its intellectual property to India for very little return (PARI, 2018, p. 83).

Former Denel Board Chair, Martie Janse van Rensburg emphasised that the 2011 Board did not have any plans to establish Denel Asia, as was reported on the Denel website press release on 11 May 2016. She positioned herself and the former Board as firm critics of the plan, saying,

I am convinced that although the 2011 Board was open and continually explored good partnerships ... it would not have considered nor approved a partnership in the form reported to have been the case with Denel Asia ... I respectfully contend that the Denel Asia establishment makes no economic sense for Denel. (Janse van Rensburg, 2019, pp. 44-46)

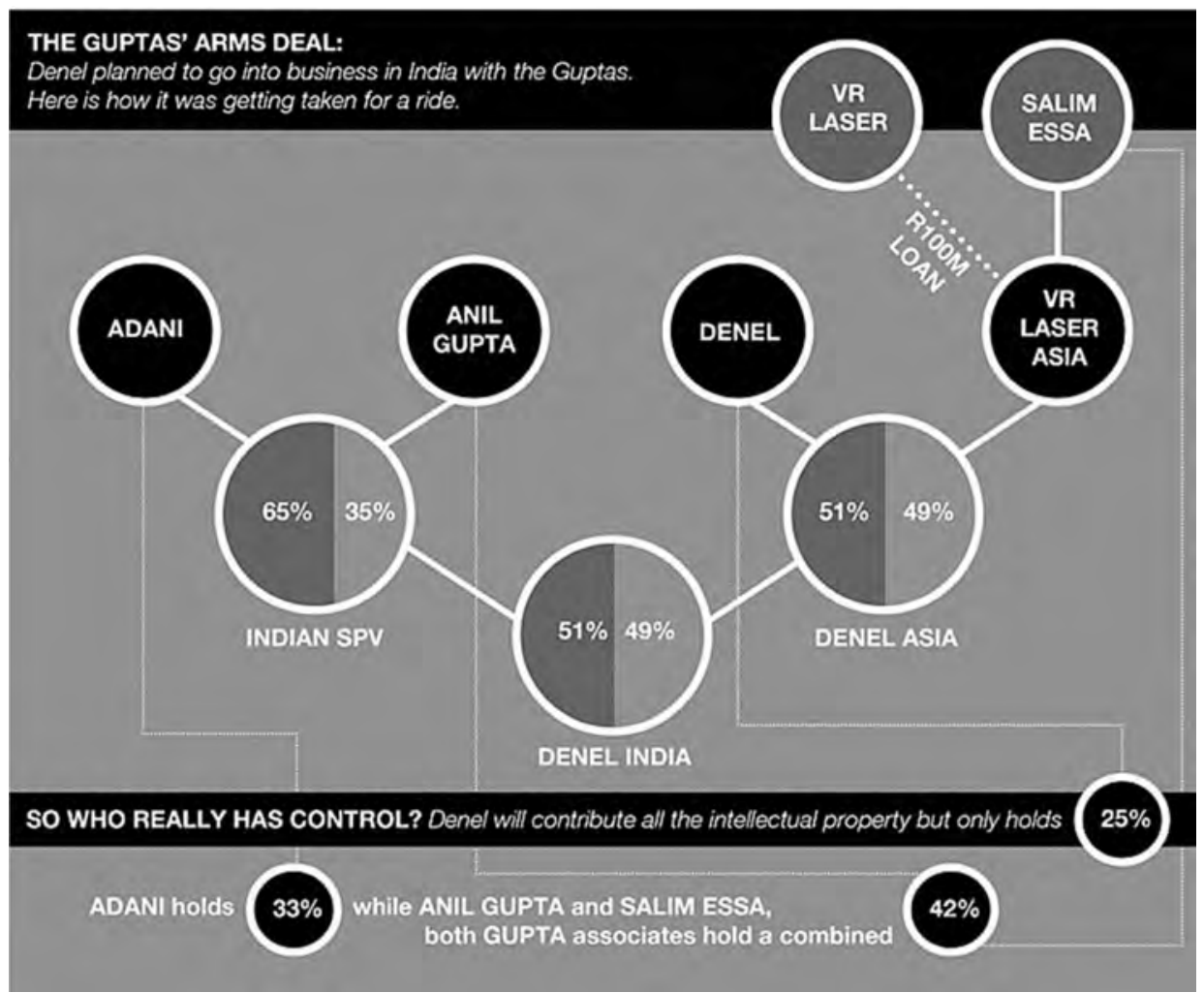

FIGURE 8.2 Breakdown of Gupta shareholding in VR Laser Deal Source: amaBhungane (2017) 


\subsubsection{The Costly Treasury Shuffles}

The \#GuptaLeaks emails indicate that Denel Executives knew they would not be making a windfall and would only take home the spoils of a very skewed deal. Why would an SOE accept such a poor bargain? Why did the Denel Board approve such a loss? From this point in Denel's capture, it is imperative to understand the political manoeuvrings that lined up all the players and institutions.

It is reasonable to deduce that the capture of Denel could not have been affected had those with political power not done the bidding of the Guptas. With the Guptaorchestrated corporate arrangements in place, governance institutions like Denel's Board and Executives compliant, all was set to launch a deal that would loot the state. The timing and sequence of events of what follows is significant.

In October 2015, the Board, headed by Mantsha, put through a Section 54 application of the Public Finance Management Act (PMFA) to Public Enterprise Minister Lynn Brown's department, a document that regulates all government revenue and expenditure to make sure finances are properly managed by the appropriate people with oversight from the Treasury. On 23 November 2015, Brown conditionally approved Denel's negotiations with VR Laser Asia to form Denel Asia (PARI, 2018, p. 73).

The PFMA for Denel Asia detailed potential business worth R9.3bn, with R8bn coming from business with India alone. Brown's conditional approval was not enough to seal the deal, it also needed the authority of a sympathetic Minister of Finance. On 9 December 2015, Treasury officials met with Denel to grill them about the Denel Asia deal, demanding to know why they had not sought permission from or registered the prospective deal with Treasury with a Section 54 application that oversaw joint ventures (PARI, 2018). Then Finance Minister, Nhlanhla Nene, refused to rubber stamp the deal - it so happens it was his last day in the job. On that day at about 20:00pm, then President Jacob Zuma replaced Nene with little known ANC "back bencher" Des van Rooyen, causing outrage and consternation politically, economically and in civil society (Bhorat et al., 2017). Van Rooyen was at the helm for all of four days, but the damage done was substantial.

Considering all the pending business contracts that required Treasury's authorisation, it is plausible to draw the conclusion that Zuma positioned Van Rooyen to approve the deals the Guptas stood to benefit from and which Nene refused to sign. They were:

- The R1tn Russian nuclear deal that proposed South Africa would invest in a fleet of nuclear power stations. Uranium One, renamed Shiva Mine was acquired by the Gupta business, Oakbay for R270m, thanks to a R250m loan from the Industrial 
Development Corporation (IDC), a state development finance institution. The mine was projected to become highly profitable were it to supply the nuclear fleet.

- A Transnet contract initially worth R34bn that eventually ballooned to R54bn awaited approval. This deal would also have benefited VR Laser who were positioned to be the local component producers for the locomotives.

- Denel Asia awaited Treasury's green light to start trading from Hong Kong. VR Laser held $49 \%$ shares in this venture and would benefit from Denel's intellectual property.

Van Rooyen's biggest defence is that he never signed off any deals as Minister, but it is alleged that he did facilitate the sharing of confidential government information with the Gupta network (amaBhungane, 2017; Fuzile, 2018). Van Rooyen came on board with two advisors, one of them Mohamed Bobat, a Gupta business associate linked to consulting firm Trillian (Haffajee, 2018). Bobat was later to craft proposals from Trillian to the Department of Co-operative Governance to do business. It is alleged Bobat used confidential government information like strategic government budgets, spending and procurement plans to draft these business proposals and that he had access to this information thanks to Van Rooyen's work during his four day stint as head of Treasury (Haffajee, 2018; Jika \& Skiti, 2018). It gave Trillian the opportunity to shape itself into the perfect government partner, an act tantamount to insider trading. This alleged exchange makes Van Rooyen a key agent in state capture.

It is not coincidence then, that after numerous requests, Denel submitted its application to form Denel Asia to Treasury only on 11 December 2015, landing straight on Van Rooyen's new desk. On the fourth day in office, Van Rooyen was replaced by Pravin Gordhan after Zuma bowed to intense pressure, but not before an estimated R500bn was lost in equities and bonds on the Johannesburg Stock Exchange (JSE), not to mention lost opportunities (Hogg, 2016).

\subsubsection{PMFA Slip-Ups and Loopholes}

Without Treasury's official green light, Denel Asia was incorporated on 29 January 2016 but it still was not allowed to trade without the Department's approval. Three months later in April 2016, then Finance Minister Pravin Gordhan declared Denel Asia illegal because the partnership between Denel and VR Laser had flouted PFMA protocol. In a media statement issued on 13 April 2016, Treasury mentions a violation of Section 54(2) of the PFMA. The section requires the SOE to inform Treasury of its intentions and to exhaustively detail the nature and operations of the future business. Treasury also cites violation of Section 51(1)(g) of the PFMA which requires its approval before an SOE Board can establish a company (National Treasury, 2016). 
The Parliamentary Portfolio Committee for Public Enterprises met in May 2016 to discuss Denel Asia's arrested state of affairs. There the acting CFO, Odwa Mhlwana, and the Denel Board, headed by Mantsha, defended their position. They insisted that the non-reply from Treasury to their 11 December 2015 submission of the PFMA was tantamount to a tacit agreement.

Mr Mantsha said 'If you do not receive any response from the shareholder department you may deem that the approval has been granted after the expiry of 30 days.' Those 30 days expired on the 12 January 2016. (Mhlwana quoted in PMG, 2016)

While such a loophole existed, Treasury did not entertain Denel's defence, reminding the company that a request for outstanding information, prior to submitting its application on 11 December 2015 still had not been satisfied, and that Treasury therefore could not make a decision on the application as they did not have enough information (National Treasury, 2016).

After about a year of standoffs with Treasury, Denel approached the courts in March 2017 asking the court to legalise the Denel Asia partnership. Mantsha argued Denel had a difference of opinion on interpretation of PFMA regulations which did not mean the company had broken the rules (Hunter, 2018). Just days later on 31 March 2017, Gordhan was removed as Finance Minister along with his deputy, Mcebici Jonas, and replaced by Malusi Gigaba. Gigaba took up Treasury's line of argument, instructing Denel to drop its court application, deregister Denel Asia and dissolve the partnership with Gupta-linked VR Laser. Denel officially cut ties with VR Laser in August 2017.

I wish to welcome the decision by Denel to cut ties with Denel Asia and to call off the legal case against National Treasury. It is a statement of good governance. (Gigaba in CNBC Africa, 2017)

\subsection{THE COSTS OF STATE CAPTURE FOR DENEL}

Come December 2017, Denel ran into liquidity problems with labour unions sounding the alarm that December salaries and 13th cheques would not be paid in time for Christmas (Child, 2017). An official Denel communication on 15 December 2017 said the company would be able to honour their 4000 employee salaries after intensive meetings with government. What became clearer was that the Public Investment Corporation (PIC) had bought a large share of Denel's debt in December 2017, and more in September and December 2018. This took the PIC's Denel bond share from R350m in March 2017 to R2.8bn in December 2018 (Winning \& Bavier, 2018). From a standing book order of R30bn, Denel's prospective sales plummeted to just R18bn by March 2017. The fallout from the botched Denel Asia deal was severe, 
including reputational damage, lost opportunities and millions wasted in consulting fees for a venture that came to nought.

Denel's Annual report for 2017/18 shows how revenues dropped but it is the earnings before interest and tax (EBIT) figures which are most telling, being almost three times lower than the previous year. It points to the devasting loss to the public purse and the need for government bailouts, which has amounted to R1bn for the past financial year 2018 (Masondo, 2019a).

\begin{tabular}{|lrrr|}
\hline FINANCIAL AND OPERATIONAL REVIEW & \multicolumn{3}{c|}{ GROUP } \\
\hline & \multicolumn{3}{c}{} \\
\cline { 2 - 4 } & $2017 / 18$ & $\begin{array}{r}2016 / 17 \\
\text { (Restated) }\end{array}$ & $\begin{array}{r}2015 / 16 \\
\text { (Restated) }\end{array}$ \\
\cline { 2 - 4 } & Rm & Rm & 8422 \\
\hline Revenue & 4998 & 8057 & 1743 \\
Gross (loss)/profit & $(121)$ & 1821 & 288 \\
Other income & 160 & 135 & $(1455)$ \\
Operating expenditure & $(1726)$ & $(1555)$ & 708 \\
Earnings before interest and tax (EBIT) & $(1461)$ & 556 & $(193)$ \\
Net finance costs & $(292)$ & $(251)$ & 476 \\
Net (loss)/profit & $(1758)$ & 282 & \\
\hline
\end{tabular}

FIGURE 8.3 Extract of Denel Financial Statements Source: Denel Annual Report 2017/18 (Denel, 2018)

In June 2019, severe liquidity problems again threatened Denel's employees but thanks to an anonymous lender, salaries could be paid in the nick of time. Current Minister of Public Enterprises, Pravin Gordhan, was unequivocal about the reason for Denel's woes saying,

There is no clearer example of the damaging effects of state capture than the financial strain and uncertainty that the 3500 Denel employees and the families will feel each month as a consequence of what we actually see. (Gordhan in Matya, 2019)

Despite a new Board and a clean-up strategy, Denel again made headlines in September 2019 after it failed to make good on a R250m deal for 40 Casspirs with Chad (Masondo, 2019a). It is alleged that Denel officials had irregularly appointed VR Laser as manufacturers in 2017 and had given them the intellectual property rights without following procurement procedures. This happened despite Denel having developed the vehicle in the first place and having in-house capacity to produce the Casspirs themselves. VR Laser was placed under business rescue when the Guptas fled the country in 2018, with all assets auctioned and the intellectual property (IP) rightfully returned to Denel, according to business rescue practitioners. But officials were still caught in a fair scramble, unable to agree about the legalities to get the job done (Masondo, 2019a). 


\subsection{CONCLUSION}

The R250m Chadian deal is just one amongst the latest revelations of losses to the company that Denel Executives say amount to R30bn in lost revenue from 2013-2019 (Masondo, 2019b). Claims of kickbacks for Gupta associates, theft of Denel's IP and numerous instances of fraud and corruption are detailed in a Special Investigations Unit (SIU) report that was submitted to the presidency in 2018. President Cyril Ramaphosa has now given the SIU permission to investigate. It is alleged that former and current employees handed IP rights to Saudi Arabian Military Industries (Sami) with at least 20 former engineers now in Sami's employ (Masondo, 2019b). These mounting losses make sense of Denel's revenue of R3.76bn for the 2018/19 financial year, even lower than takings in the previous year (Denel, 2019). It is evident that the cost of state capture continues to batter the company.

Since the new Board took office in May 2018, the company has attempted to reduce its staggering operational costs by cancelling onerous contracts, shedding non-core divisions and portfolios and letting 900 employees go, mostly through voluntary packages (Mabena, 2019). Denel's CFO projects moderate growth over the next four years, but with debt of R3.4bn, being a profitable national strategic asset is still a far way off. Stringent oversight by Treasury and the Department of Public Enterprises is reassuring but not a guarantee that state capture networks have been dismantled.

The culture of corruption dating back to the apartheid era sanction busters and the Arms Deal has not been given a proper reckoning, with nobody yet being held to account. Key Zuma-era state capture actors like Mantsha have been charged with corruption by civil society group OUTA, the Organisation Undoing Tax Abuse, in 2017, along with Eskom and Home Affairs officials. The activists have called for the new Denel Board to investigate former Board member Nkopane "Sparks" Motseki; CEO of Denel Land Systems, Stephan Burger and former CEO Zwelakhe Ntshepe (Fin24, 2019).

Coupled with the shady operations and violent ends of the global arms trade through history, Denel's fate will always be tied to profiteering from war. Between 2016 and 2017, Denel earned R3bn from arms sales to Saudi Arabia and the United Arab Emirates, fuelling a humanitarian crisis in Yemen (Dadoo \& Adam, 2018). Denel Casspirs have also supported India's occupation of Kashmir (defenceWeb, 2019).

The apartheid relic is not only a drain on the public purse and a threat to democracy, it also taints foreign policy. To keep Denel viable means to support the global war machinery, contrary to South Africa's defence of human rights. Perhaps it is time to sell it off, it serves us none and costs too much - in public money and lives across the world. 


\section{References}

amaBhungane (2017) '\#GuptaLeaks: How the Guptas screwed Denel', Daily Maverick. [Online]. https://bit.ly/2VD1bw2 (Accessed 8 October 2019).

Arms Procurement Commission (2016) 'Commission of Inquiry into Allegations of Fraud, Corruption, Impropriety or Irregularity in the Strategic Defence Procurement Package (Arms Procurement Commission)', Government Gazette. Pretoria: Department of Justice and Constitutional Development. [Online]. https://bit.ly/3AoGOBt (Accessed 22 October 2020).

Batchelor, P. \& Willet, S. (1998) Disarmament and defence industrial adjustment in South Africa, Stockholm International Peace Research Institute. New York: Oxford University Press.

Bezuidenhout, J. (2019) 'Businessman recounts sneaky Gupta acquisition of VR Laser', Daily Maverick. [Online]. https://bit.ly/3xvdzv9 (Accessed 26 November 2019).

Bhorat, H., Buthelezi, M., Chipkin, I., Duma, S., Mondi, L., Peter., C., Qobo, M., Swilling, M. \& Friedenstein, H. (2017) Betrayal of the Promise: How South Africa is being stolen, State Capacity Research Project. South Africa. [Online]. https://bit.ly/3jvidnX

Child, K. (2017) 'Denel blows Christmas: arms dealer runs out of cash to pay staff', Times Live. [Online]. https://bit.ly/3fCdW0T (Accessed 26 November 2019).

CNBC Africa (2017) Arms maker Denel cuts ties with the Gupta family. [Online] https://bit. ly/3jzHe17 (Accessed 9 October 2019).

Cock, J. \& Mckenzie, P. (1998) 'From Defence to Development: Redirecting Military Resources in South Africa', International Development Research Centre. Cape Town: International Development Research Centre. [Online].https://bit.ly/3itDRti

Corruption Watch (2018) Evidence for the People's Tribunal on Economic Crime: The 1999 Arms Deal, People's Tribunal on Economic Crime. [Online]. https://bit.ly/ 3fGGkis
Dadoo, S. \& Adam, Z. (2018) 'Yemenis' blood is on SA's hands', Mail \& Guardian. [Online]. https://bit.ly/3Crm3XS (Accessed 26 November 2019).

Davis, T. \& Mutemwa-Tumbo, D. (2019) ‘Guns, lies, politics: seeking a judicial inquiry into arms deal's whitewash commission', Times Live. [Online]. https://bit.ly/3AilWMk (Accessed 26 November 2019).

DefenceWeb (2019) South Africa and India seeking defence industry collaboration. [Online]. https://bit.ly/3xv]knG (Accessed 26 November 2019).

Denel (2007) Denel Annual Report 2007 Presentation to the Portfolio Committee on Public Enterprises. [Online]. https://bit. ly/3fGNPWA (Accessed 9 January 2020).

Denel (2011) Annual Report 2011.

Denel (2016) Denel's Venture In South East Asia Forms Part Of Global Growth Strategy. [Online]. https://bit.ly/3lw5ow5 (Accessed 23 October 2020).

Denel (2018) Denel Integrated Report 2017/18. [Online]. https://bit.ly/3rTUbqi (Accessed 9 January 2020).

Denel (2019) Denel Integrated Report 2018/19. [Online]. https://bit.ly/37mbWW4 (Accessed 9 January 2020).

Dunne, P. \& Haines, R. (2002) 'Defence Industrial Restructuring and Economic Growth in South Africa,' Trade and Industrial Policy Secretariat (TIPS). [Online]. https://bitly/ 3lLu0kH (Accessed 9 January 2020).

Ensor, L. (2008) 'Denel Firm Costs Taxpayer R660m', Business Day, 23 October. [Online]. https://bit.ly/2VoMnRJ (Accessed 27 September 2019).

Fin24 (2019) Hold wrongdoers at Denel accountable - OUTA. [Online]. https://bit. ly/3ilsrle (Accessed 26 November 2019).

Fuzile, L. (2018) 'Statement and Documents Submitted by Lungisa Fuzile', Commission of Inquiry into State Capture.

Haffajee, F. (2018) 'How Gupta-linked adviser went over Van Rooyen's head - ex-Treasury DG', News24. https://bit.ly/3ltVNpB (Accessed 17 October 2019). 
Hart, K. \& Padayachee, V. (2013) 'A history of South African capitalism in national and global perspective', Transformation: Critical Perspectives on Southern Africa, 81(1):55-85. https://doi.org/10.1353/trn.2013.0004

Henk, D. (2004) 'Guns and Butter: Reframing South Africa's Arms Industry', African Security Review, 13(3):13-19. https://doi. org/10.1080/10246029.2004.9627299

High Court of South Africa: North Gauteng (2019) Corruption Watch and Another v Arms Procurement Commission and Others (81368/2016) [2019] ZAGPPHC 351. [Online].https://bit.ly/3s6KZzj (Accessed 22 October 2020).

Hogg, A. (2016) 'Calculating Zuma’s R500bn \#Nenegate blunder - Rand depreciation excluded', BizNews. [Online]. https://bit.ly/ 3jlzAaB (Accessed 25 November 2019).

Hunter, Q. (2018) 'Zuma’s new lawyer Mantsha was once struck off the roll, and later delivered Denel to the Guptas - basically, he's ideal for the job', Daily Maverick. [Online]. https:// bit.ly/2TX6qpK (Accessed 26 November 2019).

Hunter, Q. \& Cowan, K. (2017) 'Gigaba’s advisor emerges as Gupta Home Affairs fixer', Times Live. [Online]. https://bit.ly/3yDn78V (Accessed 22 October 2020).

Janse van Rensburg, M. (2019) 'Statement and Documents Submitted by Martie Janse van Rensburg, Commission of Inquiry into State Capture. [Online]. https://bit.ly/3jm7dcy

Jika, T. \& Skiti, S. (2018) 'Van Rooyen lost no time in the treasury', Mail \& Guardian. [Online]. https://bit.ly/3fwxzY7 (Accessed 17 October 2019).

Jiyane, M.J. (2019) 'Statement and Documents Submitted by Madoda John Jiyane', Commission of Inquiry into State Capture. [Online]. https://bit.ly/3AcN9jC

Letsoalo, M., Faull, L. \& Mataboge, M. (2011) 'Veterans' official in private deals', Mail \& Guardian. [Online]. https://bit.ly/37izLOm (Accessed 6 October 2019).

Leuvennink, J. (2001) 'Exports boost Denel', News24. [Online]. https://bit.ly/3A2tzGG (Accessed 26 September 2019).
Mabena, S. (2019) 'Success in sight' for Denel after record orders', The Citizen. [Online]. https://bit.ly/3xjPTdb (Accessed 26 November 2019).

Martin, G. (2014) 'Huge Indian market to become available to Denel as blacklisting resolves', defenceWeb. [Online]. https://bit. ly/3ypKTFh (Accessed 18 September 2019).

Masondo, S. (2019a) 'Denel blows R250m arms deal with Chad', City Press. [Online]. https:// bit.ly/3io8qAH (Accessed 26 November 2019).

Masondo, S. (2019b) 'Denel lost R30bn in deals due to Gupta bribes', City Press. [Online]. https://bit.ly/3rYerXV (Accessed 26 November 2019).

Matya, L. (2019) 'Denel employees to receive full salaries', $S A B C$. [Online]. https://bit.ly/ 3yrwiJp (Accessed 9 October 2019).

Mitchley, A. (2019) 'Seriti arms deal report can no longer be used as a defence by Zuma - former MP Andrew Feinstein', News24. [Online]. https://bit.ly/3rSgY5U (Accessed 26 November 2019).

Modise, J. (1999) Address by the Minister of Defence on the Defence Budget Vote', 9 March, The Arms Deal Virtual Press Office. [Online]. https://bit.ly/2VoO6GH (Accessed 27 October 2020).

National Treasury (2016) Statement On Reports That Denel Established A Joint Venture, 13 April. [Online]. https://bit.ly/3yrFqgT

Public Affairs Research Institute (PARI) (2018) 'Evidence for the People's Tribunal on Economic Crime 3. State Capture: The case of Denel and VR Laser', People's Tribunal on Economic Crime. [Online]. https://bit. ly/3CfrlqC

Parliamentary Monitoring Group (PMG) (2016) Public Enterprises Committee: Denel board on VR Laser Asia and suspension of its executives. [Online]. https://bit.ly/2TYF6Ye (Accessed 27 October 2020).

Parliamentary Monitoring Group (PMG) (2018) Gupta Family Naturalisation: Parliamentary Inquiry; with the Minister. [Online]. https:// bit.ly/3lvuQlv (Accessed 22 October 2020). 
Pressly, D. (2005) 'Denel 'did nothing wrong in India", Mail \& Guardian. [Online]. https:// bit.ly/3fwt3sw (Accessed 10 October 2019).

Saloojee, R. (2019) 'Statement and Documents Submitted by Riaz Saloojee', Commission of Inquiry into State Capture. [Online]. https:// bit.ly/3Abfreh

Sylvester, J. \& Seegers, A. (2011) 'South Africa'S Strategic Arms Package: a Critical Analysis', Scientia Militaria - South African Journal of Military Studies, 36(1):52-77. https://doi. org/10.5787/36-1-45
Van Vuuren, H. (2017) Apartheid guns and money: a tale of profit. Johannesburg: Jacana Media.

Wessels, A. (2010) 'The United Nations Arms Embargo Against South Africa, 1977-1994, War and Society, 29(2):137-153. https:// doi.org/10.1179/204243410X126744 22128957

Winning, L. \& Bavier, J. (2018) 'PIC buys up Denel's bonds', Moneyweb. [Online]. https://bit.ly/2WX5dQo (Accessed 9 January 2020). 



\section{APPENDIX}

\begin{tabular}{|c|c|c|c|c|}
\hline $\begin{array}{l}\text { Case Study } \\
\text { in State } \\
\text { Capture }\end{array}$ & Status & Summary Description & $\begin{array}{l}\text { Investigation } \\
\text { Body / } \\
\text { Source of } \\
\text { Evidence }\end{array}$ & $\begin{array}{l}\text { Government } \\
\text { Entity } \\
\text { Implicated }\end{array}$ \\
\hline \multicolumn{5}{|c|}{ Scandals Connected to Jacob Zuma, Guptas, Other Key Networks and ANC Politics } \\
\hline $\begin{array}{l}\text { The State } \\
\text { of Capture } \\
\text { report- } \\
\text { focuses } \\
\text { on Guptas' } \\
\text { relationship } \\
\text { with Jacob } \\
\text { Zuma and } \\
\text { their alleged } \\
\text { influence on } \\
\text { the affairs } \\
\text { of state }\end{array}$ & $\begin{array}{l}\text { First complaint } \\
\text { was received } \\
\text { in March } 2016 \\
\text { and the report } \\
\text { was released in } \\
\text { November } 2016 .\end{array}$ & $\begin{array}{l}\text { Investigation into complaints of alleged improper } \\
\text { and unethical conduct by the President and } \\
\text { other State Functionaries, relating to alleged } \\
\text { improper relationships and involvement of the } \\
\text { Gupta Family in the removal and appointment } \\
\text { of Ministers and Directors of State-Owned } \\
\text { Enterprises (SOEs), resulting in improper and } \\
\text { possibly corrupt award of State Contracts and } \\
\text { Benefits to the Gupta Family's Businesses. } \\
\text { The report details numerous allegations of } \\
\text { the Guptas' involvement in affairs of the state } \\
\text { and their irregular activities that enable rent } \\
\text { extraction. The findings were not conclusive } \\
\text { and the remedial action was to establish a } \\
\text { commission of inquiry into state capture (to } \\
\text { be appointed by the President, but with a } \\
\text { judge selected by the Chief Justice). Litigation } \\
\text { endeavoured to delay or prohibit the report's } \\
\text { release and implementation of remedial actions, } \\
\text { but failed, and the commission was established } \\
\text { in } 2018 \text {. }\end{array}$ & $\begin{array}{l}\text { - Public } \\
\text { Protector, } \\
\text { followed by } \\
\text { litigation }\end{array}$ & $\begin{array}{l}\text { - GCIS (The } \\
\text { New Age) } \\
\text { - Eskom } \\
\text { (Optimum) } \\
\text { - Transnet } \\
\text { (Regiments/ } \\
\text { Trillian) } \\
\text { - Denel } \\
\text { - SAA (The } \\
\text { New Age) } \\
\text { - SABC (The } \\
\text { New Age) } \\
\text { - Department of } \\
\text { Finance } \\
\text { - Transport } \\
\text { (SAA) } \\
\text { - Communica- } \\
\text { tions (SABC } \\
\text { \& GCIS) }\end{array}$ \\
\hline $\begin{array}{l}\text { Zondo } \\
\text { Commission }\end{array}$ & $\begin{array}{l}\text { Established } \\
\text { in 2018, with } \\
\text { anticipated } \\
\text { conclusion being } \\
\text { the end of } 2021 .\end{array}$ & $\begin{array}{l}\text { Formally titled the Judicial Commission of } \\
\text { Inquiry into Allegations of State Capture, } \\
\text { Corruption and Fraud in the Public Sector } \\
\text { including Organs of State, the Commission } \\
\text { was promulgated by then President Zuma in } \\
\text { response to the remedial actions as outlined in } \\
\text { the Public Protector's State of Capture report. } \\
\text { As of June } 2021 \text {, the Commission that started } \\
\text { in August } 2018 \text { has held more than } 418 \text { days } \\
\text { of hearings of over } 330 \text { testimonies (generating } \\
\text { over } 71000 \text { pages of transcript). The inquiry's } \\
\text { terms of reference were expansive and, as } \\
\text { such, the scope of investigations went beyond } \\
\text { merely looking into the Gupta-related cases, } \\
\text { covering other networks (e.g., Bosasa) as well } \\
\text { as other government institutions (e.g., role } \\
\text { of Parliament). }\end{array}$ & $\begin{array}{l}\text { - Zondo } \\
\text { Commission }\end{array}$ & $\begin{array}{l}\text { Various } \\
\text { work-streams } \\
\text { covering } \\
\text { inter alia: } \\
\text { - SOEs } \\
\text { (Eskom, } \\
\text { Transnet, } \\
\text { Denel, SAA) } \\
\text { - Free State } \\
\quad \text { Provincial } \\
\text { Government } \\
\text { - Bosasa } \\
\text { - SARS } \\
\text { - Law } \\
\text { enforcement } \\
\text { - State Security } \\
\text { Agency (SSA) } \\
\text { - The New Age } \\
\text { \& ANN7 } \\
\text { - Role of } \\
\text { Parliament } \\
\text { and ANC }\end{array}$ \\
\hline
\end{tabular}




\begin{tabular}{|c|c|c|c|c|}
\hline $\begin{array}{l}\text { Case Study } \\
\text { in State } \\
\text { Capture }\end{array}$ & Status & Summary Description & $\begin{array}{l}\text { Investigation } \\
\text { Body / } \\
\text { Source of } \\
\text { Evidence }\end{array}$ & $\begin{array}{l}\text { Government } \\
\text { Entity } \\
\text { Implicated }\end{array}$ \\
\hline \multicolumn{5}{|c|}{ Scandals Connected to Jacob Zuma, Guptas, Other Key Networks and ANC Politics } \\
\hline Bosasa & $\begin{array}{l}\text { Dating back to a } \\
2009 \text { SIU report. } \\
\text { Investigations and } \\
\text { various litigations } \\
\text { are ongoing. }\end{array}$ & $\begin{array}{l}\text { In 2019, former Bosasa C00, Anglo Agrizzi, } \\
\text { testified at the Zondo Commission, detailing } \\
\text { the acts and long history of corruption between } \\
\text { various Bosasa companies predominantly } \\
\text { owned by Gavin Watson, and numerous } \\
\text { government entities/departments. The } \\
\text { testimony of Agrizzi (and other former Bosasa } \\
\text { employees) corroborated the findings of a } \\
2009 \text { SIU investigation that alleged corruption } \\
\text { in several contracts Bosasa had with the } \\
\text { Department of Correctional Services. Criminal } \\
\text { court proceedings have been initiated based } \\
\text { on the } 2009 \text { SIU investigation, along with new } \\
\text { investigations initiated by SARS and other law } \\
\text { enforcement entities. }\end{array}$ & $\begin{array}{l}\text { - Special } \\
\text { Investi- } \\
\text { gation } \\
\text { Unit (SIU) } \\
\text { - Zondo } \\
\text { Commission }\end{array}$ & $\begin{array}{l}\text { - Department of } \\
\text { Correctional } \\
\text { Services } \\
\text { - Department of } \\
\text { Justice } \\
\text { - Department of } \\
\text { Home Affairs } \\
\text { - Department of } \\
\text { Transport } \\
\text { - Various SOEs } \\
\text { (e.g., SAPO, } \\
\text { ACSA) } \\
\text { - National } \\
\text { Prosecuting } \\
\text { Authority } \\
\text { (NPA) } \\
\text { - Members of } \\
\text { Parliament }\end{array}$ \\
\hline Arms Deal & $\begin{array}{l}\text { Various } \\
\text { investigations and } \\
\text { sources, dating } \\
\text { back to 1990s. } \\
\text { Most significant } \\
\text { source being } \\
\text { through Seriti } \\
\text { Commission. } \\
\text { Corruption case } \\
\text { against Zuma is } \\
\text { ongoing. }\end{array}$ & $\begin{array}{l}\text { Commission of Inquiry into allegations of fraud, } \\
\text { corruption, impropriety, or irregularity in the } \\
\text { Strategic Defence Procurement Packages } \\
\text { (SDPP). Various court cases related to } \\
\text { allegations of corruption against Jacob Zuma. } \\
\text { On Monday, } 24 \text { October 2011, the President } \\
\text { announced the Commission chaired by Judge } \\
\text { Seriti. The findings of the Commission were that } \\
\text { there was "no evidence" of corruption, but this } \\
\text { is seen by many to have been a whitewash. The } \\
\text { report was taken on review and set aside in } \\
\text { August 2019. The corruption case against Zuma } \\
\text { is ongoing before the courts. }\end{array}$ & $\begin{array}{l}\text { - Seriti } \\
\text { Commission } \\
\text { - Various } \\
\text { court cases }\end{array}$ & $\begin{array}{l}\text { Initially: } \\
\text { - South African } \\
\text { National } \\
\text { Defence } \\
\text { Force } \\
\text { - Members of } \\
\text { Parliament } \\
\text { Allegations also } \\
\text { involve: } \\
\text { - NPA } \\
\text { - SSA }\end{array}$ \\
\hline $\begin{array}{l}\text { Nkandla } \\
\text { Security } \\
\text { Upgrades }\end{array}$ & $\begin{array}{l}\text { Investigation } \\
\text { started in } \\
\text { November } 2012 . \\
\text { Report on } \\
\text { investigation } \\
\text { was released in } \\
\text { March } 2014 .\end{array}$ & $\begin{array}{l}\text { Report on security upgrades to President } \\
\text { Zuma's homestead in Nkandla. The investigation } \\
\text { found that the President unduly benefited from } \\
\text { the upgrades and as part of remedial actions } \\
\text { the President was required to pay back a portion } \\
\text { of the costs of the upgrades. Zuma instructed } \\
\text { that SAPS undertake their own investigation, } \\
\text { which sought to rationalise the expenses (fire- } \\
\text { pool report). Parliament accepted this alternative } \\
\text { report, but major court cases followed, } \\
\text { ultimately declaring that the Public Protector's } \\
\text { remedial actions are binding. President and } \\
\text { Parliament failed to uphold the Constitution. } \\
\text { President ordered to "pay back the money". }\end{array}$ & $\begin{array}{l}\text { - Public } \\
\text { Protector's } \\
\text { Secured } \\
\text { in Comfort } \\
\text { report, } \\
\text { followed by } \\
\text { litigation }\end{array}$ & $\begin{array}{l}\text { - Department of } \\
\text { Public Works } \\
\text { - South African } \\
\text { Police Service }\end{array}$ \\
\hline
\end{tabular}




\begin{tabular}{|c|c|c|c|c|}
\hline $\begin{array}{l}\text { Case Study } \\
\text { in State } \\
\text { Capture }\end{array}$ & Status & Summary Description & $\begin{array}{l}\text { Investigation } \\
\text { Body / } \\
\text { Source of } \\
\text { Evidence }\end{array}$ & $\begin{array}{l}\text { Government } \\
\text { Entity } \\
\text { Implicated }\end{array}$ \\
\hline \multicolumn{5}{|c|}{ Scandals Connected to Jacob Zuma, Guptas, Other Key Networks and ANC Politics } \\
\hline $\begin{array}{l}\text { Private } \\
\text { Aircraft } \\
\text { Landing at } \\
\text { Waterkloof } \\
\text { Airforce Base } \\
\text { and Gupta } \\
\text { Sun City } \\
\text { Wedding }\end{array}$ & May 2013. & $\begin{array}{l}\text { In 2013, justice, crime prevention, and } \\
\text { security cluster (JCPS) - a cabinet structure } \\
\text { composed of various ministries - undertook an } \\
\text { investigation into the Landing of a Commercial } \\
\text { aircraft at Air Force Base Waterkloof (report } \\
\text { titled the same). The investigation revealed that } \\
\text { the Guptas initially tried to organise a special } \\
\text { landing at OR Tambo International Airport, but } \\
\text { was turned down. They then approached the } \\
\text { Indian High Commission who re-designated the } \\
\text { wedding entourage as an official delegation to } \\
\text { secure a landing at the Waterkloof base. The } \\
\text { wedding held at Sun City was attended by a } \\
\text { number of high-profile ANC politicians and was } \\
\text { paid for in part by moneys looted from the Vrede } \\
\text { Dairy Farm project. }\end{array}$ & $\begin{array}{l}\text { - Report by } \\
\text { JPCS } \\
\text { - Zondo } \\
\text { Commission } \\
\end{array}$ & \begin{tabular}{|l} 
- Department of \\
International \\
Relations and \\
Cooperation \\
(DIRCO) \\
- Department of \\
Defence \\
- Department of \\
Transport
\end{tabular} \\
\hline $\begin{array}{l}\text { Free State } \\
\text { Provincial } \\
\text { Capture, } \\
\text { includes } \\
\text { Vrede Dairy } \\
\text { Farm and } \\
\text { Asbestos } \\
\text { Contracts }\end{array}$ & Ongoing. & $\begin{array}{l}\text { The Vrede Dairy Farm project was initiated } \\
\text { by the Free State Provincial Government as a } \\
\text { development project, however, in partnering with } \\
\text { a Gupta-linked company Estina, government } \\
\text { funds were looted. In 2018, the Public } \\
\text { Protector released a report on their } 2018 \\
\text { investigation, but it was taken on review and } \\
\text { set aside by the courts. The second part of the } \\
\text { investigation is yet to be finalised. The NPA } \\
\text { laid criminal charges against Gupta associates } \\
\text { and implicated government officials. Court } \\
\text { proceedings are ongoing. } \\
\text { Significant testimony and evidence have been } \\
\text { presented at the Zondo Commission regarding } \\
\text { the Vrede Farm case, as well as the asbestos } \\
\text { inspection project (criminal proceedings are also } \\
\text { underway). Both projects implicate high-profile } \\
\text { politicians and senior officials manipulating } \\
\text { government process. }\end{array}$ & $\begin{array}{l}\text { - Public } \\
\text { Protector } \\
\text { reports } \\
\text { - Zondo } \\
\text { Commission } \\
\text { - Various } \\
\text { court cases } \\
\end{array}$ & $\begin{array}{l}\text { - Free State } \\
\text { Provincial } \\
\text { Government }\end{array}$ \\
\hline $\begin{array}{l}\text { Irregular } \\
\text { removal of } \\
\text { National } \\
\text { Director } \\
\text { of Public } \\
\text { Prosecutions } \\
\text { (NDPP), } \\
\text { Mxolisi } \\
\text { Nxasana }\end{array}$ & $\begin{array}{l}\text { Inquiry instituted } \\
\text { in February } 2015, \\
\text { but was cancelled } \\
\text { in May } 2015 . \\
\text { This triggers the } \\
\text { Constitutional Court } \\
\text { cases that followed. }\end{array}$ & $\begin{array}{l}\text { Inquiry into the fitness of Mxolisi Nxasana to } \\
\text { hold office as NDPP. The Inquiry was cancelled } \\
\text { after Zuma "agreed to let Nxasana resign". He } \\
\text { was paid R17m - the balance of his ten-year } \\
\text { contract. Court cases followed detailing the } \\
\text { abuse of the presidency powers by Zuma. } \\
\text { Ultimately, Nxasana was ordered to repay } \\
\text { R17m and Zuma's appointed replacement, } \\
\text { Shawn Abrahams, was ordered to vacate office. } \\
\text { Constitutional Court found Zuma's actions to } \\
\text { be an abuse of power and in breach of his } \\
\text { constitutional obligations. }\end{array}$ & $\begin{array}{l}\text { - Cassim } \\
\text { Inquiry into } \\
\text { fitness of } \\
\text { Mxolisi } \\
\text { Nxasana to } \\
\text { hold office } \\
\text { of NDPP } \\
\text { initiated } \\
\text { by Zuma, } \\
\text { followed by } \\
\text { litigation }\end{array}$ & $\begin{array}{l}\text { - National } \\
\text { Prosecution } \\
\text { Authority }\end{array}$ \\
\hline $\begin{array}{l}\text { Political } \\
\text { killings in } \\
\text { KZN }\end{array}$ & $\begin{array}{l}\text { Established in } \\
\text { October } 2016 . \text { The } \\
\text { report was released } \\
\text { in May } 2018 .\end{array}$ & $\begin{array}{l}\text { On } 28 \text { October 2016, the Premier of the } \\
\text { Province of KwaZulu-Natal established a } \\
\text { Commission of Enquiry into the Underlying } \\
\text { Causes of the Murder of Politicians in KwaZulu- } \\
\text { Natal (KZN). }\end{array}$ & $\begin{array}{l}\text { - Moerane } \\
\text { Commission } \\
\text { of Enquiry }\end{array}$ & $\begin{array}{l}\text { - KZN Provincial } \\
\text { Government } \\
\text { - KZN Local } \\
\text { Governments }\end{array}$ \\
\hline
\end{tabular}




\begin{tabular}{|c|c|c|c|c|}
\hline $\begin{array}{l}\text { Case Study } \\
\text { in State } \\
\text { Capture }\end{array}$ & Status & Summary Description & $\begin{array}{l}\text { Investigation } \\
\text { Body / } \\
\text { Source of } \\
\text { Evidence }\end{array}$ & $\begin{array}{l}\text { Government } \\
\text { Entity } \\
\text { Implicated }\end{array}$ \\
\hline \multicolumn{5}{|c|}{ Scandals Connected to Jacob Zuma, Guptas, Other Key Networks and ANC Politics } \\
\hline \multicolumn{5}{|c|}{ State Capture of State-Owned Enterprises and Government Departments } \\
\hline $\begin{array}{l}\text { Interference } \\
\text { in operations } \\
\text { at the SABC }\end{array}$ & $\begin{array}{l}\text { The Ad Hoc } \\
\text { Committee was } \\
\text { established in } \\
\text { November } 2016 \\
\text { and final report } \\
\text { was tabled on } \\
24 \text { February } 2017 .\end{array}$ & $\begin{array}{l}\text { Parliamentary Ad Hoc Committee on the } \\
\text { SABC Board Inquiry into mismanagement and } \\
\text { interference in SABC operations. Findings } \\
\text { include evidence of Minister Faith Muthambi's } \\
\text { interference in the organisation and editorial } \\
\text { interference, in the firing of SABC } 8 \text { who } \\
\text { protested censorship of the national broadcaster } \\
\text { (on instruction from COO Hlaudi Motsoeneng). It } \\
\text { should be noted that the inquiry was preceded } \\
\text { by an investigation by the Public Protector. } \\
\text { Details are contained in the } 2014 \text { report titled } \\
\text { When Governance and Ethics Fail. }\end{array}$ & $\begin{array}{l}\text { - Parliamen- } \\
\text { tary Inquiry } \\
\text { - Preceded by } \\
\text { an investi- } \\
\text { gation by } \\
\text { the Public } \\
\text { Protector }\end{array}$ & $\begin{array}{l}\text { - SABC } \\
\text { (Department } \\
\text { of Communi- } \\
\text { cation) }\end{array}$ \\
\hline \multirow[t]{2}{*}{$\begin{array}{l}\text { Passenger } \\
\text { Rail Agency } \\
\text { of South } \\
\text { Africa } \\
\text { (PRASA) }\end{array}$} & $\begin{array}{l}\text { Complaints were } \\
\text { lodged in } 2012 \\
\text { and the report } \\
\text { was released in } \\
\text { August } 2015 \text {. }\end{array}$ & $\begin{array}{l}\text { Several cases of "mismanagement and } \\
\text { irregularities" regarding various contracts. } \\
\text { Lucky Montana was CEO at the time. One of } \\
\text { the remedial actions stipulated that National } \\
\text { Treasury was to investigate all PRASA contracts } \\
\text { from } 2012 \text { onwards with a value of R10 million } \\
\text { or more. National Treasury implemented the } \\
\text { remedial action which resulted in several } \\
\text { investigations, the details of which were leaked } \\
\text { to the public. }\end{array}$ & $\begin{array}{l}\text { - Public } \\
\text { Protector's } \\
\text { Derailed } \\
\text { report on } \\
\text { PRASA } \\
\text { - Numerous } \\
\text { investiga- } \\
\text { tions }\end{array}$ & $\begin{array}{l}\text { - PRASA } \\
\text { - Department of } \\
\text { Transport }\end{array}$ \\
\hline & $\begin{array}{l}\text { In June } 2017, \\
\text { Parliament directed } \\
4 \text { committees to } \\
\text { investigate state } \\
\text { capture. Committee } \\
\text { hearings were not } \\
\text { completed. }\end{array}$ & $\begin{array}{l}\text { In terms of the parliamentary directive, the } \\
\text { Portfolio Committee on Transport was requested } \\
\text { to establish an Inquiry into State Capture at } \\
\text { PRASA. However, the Portfolio Committee noted } \\
\text { that PRASA was not mentioned in the Public } \\
\text { Protector's State of Capture report and decided } \\
\text { they would focus on the various investigation } \\
\text { reports produced for National Treasury (as } \\
\text { recommended in Derailed report). }\end{array}$ & $\begin{array}{l}\text { - Portfolio } \\
\text { Committee } \\
\text { on Transport }\end{array}$ & $\begin{array}{l}\text { - PRASA } \\
\text { - Department of } \\
\text { Transport }\end{array}$ \\
\hline $\begin{array}{l}\text { Eskom } \\
\text { Inquiry into } \\
\text { State Capture }\end{array}$ & $\begin{array}{l}\text { In June } 2017 \text {, } \\
\text { Parliament directed } \\
4 \text { committees } \\
\text { to investigate } \\
\text { state capture. } \\
\text { Public Enterprises } \\
\text { Committee } \\
\text { report on Eskom } \\
\text { was released in } \\
\text { November } 2018 .\end{array}$ & $\begin{array}{l}\text { Extensive hearings were held by the Committee } \\
\text { detailing much of the evidence presented in } \\
\text { the Public Protector's report. The Committee } \\
\text { presented recommendations and compiled } \\
\text { a final report detailing their findings. These } \\
\text { included findings that Ministers Lynne Brown } \\
\text { and Malusi Gigaba were negligent and had to } \\
\text { be held accountable. Also recommended that } \\
\text { criminal investigations be undertaken against } \\
\text { the relevant Eskom executives. }\end{array}$ & $\begin{array}{l}\text { - Parliamen- } \\
\text { tary Inquiry }\end{array}$ & $\begin{array}{l}\text { - Eskom } \\
\text { - Department } \\
\text { of Public } \\
\text { Enterprises }\end{array}$ \\
\hline $\begin{array}{l}\text { Nugent } \\
\text { Commission } \\
\text { - SARS } \\
\text { Inquiry }\end{array}$ & $\begin{array}{l}\text { The Inquiry was } \\
\text { constituted on } \\
24 \text { May } 2018 \text { and } \\
\text { the final report } \\
\text { was released in } \\
\text { December } 2018 \text {. }\end{array}$ & $\begin{array}{l}\text { Commission of Inquiry into tax administration } \\
\text { and governance by South African Revenue } \\
\text { Service (SARS). Tom Moyane was fired based on } \\
\text { the interim report released in September } 2018 . \\
\text { The inquiry found that Moyane, with the help of } \\
\text { consultancy company Bain, had implemented } \\
\text { restructuring of the organisation, resulting in } \\
\text { gross mismanagement and erosion of SARS. } \\
\text { Moyane motivated the restructuring based on } \\
\text { the "rogue unit" narrative that has been the } \\
\text { subject of several other debunked investigations } \\
\text { and the subject of much litigation. }\end{array}$ & $\begin{array}{l}\text { - Judicial } \\
\text { Commission } \\
\text { of Inquiry } \\
\text { - Court cases } \\
\text { around the } \\
\text { "rogue unit" } \\
\text { narrative }\end{array}$ & $\begin{array}{l}\text { - SARS } \\
\text { (National } \\
\text { Treasury) }\end{array}$ \\
\hline
\end{tabular}




\begin{tabular}{|c|c|c|c|c|}
\hline $\begin{array}{l}\text { Case Study } \\
\text { in State } \\
\text { Capture }\end{array}$ & Status & Summary Description & $\begin{array}{l}\text { Investigation } \\
\text { Body / } \\
\text { Source of } \\
\text { Evidence }\end{array}$ & $\begin{array}{l}\text { Government } \\
\text { Entity } \\
\text { Implicated }\end{array}$ \\
\hline \multicolumn{5}{|c|}{ Scandals Connected to Jacob Zuma, Guptas, Other Key Networks and ANC Politics } \\
\hline \multicolumn{5}{|c|}{ State Capture of State-Owned Enterprises and Government Departments } \\
\hline $\begin{array}{l}\text { Commission } \\
\text { of Inquiry } \\
\text { into Public } \\
\text { Investment } \\
\text { Corporation } \\
\text { (PIC) }\end{array}$ & $\begin{array}{l}\text { In October } 2018 \text {, } \\
\text { the Commission } \\
\text { was constituted, } \\
\text { and the final report } \\
\text { was released in } \\
\text { March } 2020 .\end{array}$ & $\begin{array}{l}\text { Commission of Inquiry into allegations of } \\
\text { impropriety regarding Public Investment } \\
\text { Corporation (PIC). There were extensive hearings } \\
\text { on various 'dodgy' deals the PIC entered } \\
\text { into and details of political and executive } \\
\text { interference in the operations and decision- } \\
\text { making processes of the investment agency. }\end{array}$ & $\begin{array}{l}\text { - Judicial } \\
\text { Commission } \\
\text { of Inquiry }\end{array}$ & $\begin{array}{l}\text { - PIC (National } \\
\text { Treasury) }\end{array}$ \\
\hline $\begin{array}{l}\text { South African } \\
\text { Social } \\
\text { Security } \\
\text { Agency } \\
\text { (SASSA) }\end{array}$ & $\begin{array}{l}\text { Various } \\
\text { Constitutional Court } \\
\text { cases from } 2011 \\
\text { to } 2018 \text { resulted } \\
\text { in removal of CPS } \\
\text { as service provider } \\
\text { to SASSA. }\end{array}$ & $\begin{array}{l}\text { In 2014, South African Social Security Agency's } \\
\text { (SASSA) } 2012 \text { contract with CPS was found } \\
\text { to be irregular and invalid, however, due to the } \\
\text { importance of ensuring beneficiaries received } \\
\text { grants, CPS continued to be the service } \\
\text { providers until } 2018 \text {. Following a March } 2017 \\
\text { ruling, the Constitutional Court instituted a } \\
\text { Section } 38 \text { Inquiry into Minister Bathabile } \\
\text { Dlamini's personal liability for the narrowly } \\
\text { averted grant payment crisis. }\end{array}$ & $\begin{array}{l}\text { Primary } \\
\text { sources: } \\
\text { - AllPay court } \\
\text { case } \\
\text { - Black Sash } \\
\text { court case }\end{array}$ & - SASSA \\
\hline $\begin{array}{l}\text { South African } \\
\text { Airways (SAA) } \\
\text { and SAA } \\
\text { Technical }\end{array}$ & $\begin{array}{l}\text { Court case } \\
\text { to have Dudu } \\
\text { Myeni declared a } \\
\text { delinquent director } \\
\text { was launched } \\
\text { in } 2017 .\end{array}$ & $\begin{array}{l}\text { Court case was launched in } 2017 \text { by Outa and } \\
\text { the SAA Pilots' Association (SAAPA) to declare } \\
\text { Myeni a delinquent director in terms of the } \\
\text { Companies Act, based on her actions while she } \\
\text { was chairperson of the SAA Board. In 2020, the } \\
\text { High Court declared Myeni a delinquent director } \\
\text { for life. A significant amount of new evidence } \\
\text { also emerged through the Zondo Commission, } \\
\text { outlining how the operations at SAA were } \\
\text { undermined and how Myeni and others abused } \\
\text { their positions of authority. }\end{array}$ & $\begin{array}{l}\text { - Court } \\
\text { papers } \\
\text { - Zondo } \\
\text { Commission }\end{array}$ & $\begin{array}{l}\text { - SAA } \\
\text { - SAA Technical }\end{array}$ \\
\hline $\begin{array}{l}\text { Gupta Family } \\
\text { Naturalisation }\end{array}$ & $\begin{array}{l}\text { In June } 2017, \\
\text { Parliament directed } \\
4 \text { committees to } \\
\text { investigate state } \\
\text { capture. Final } \\
\text { report was tabled } \\
14 \text { March } 2019 .\end{array}$ & $\begin{array}{l}\text { Portfolio Committee on Home Affairs Inquiry into } \\
\text { the Gupta Family Naturalisation was established } \\
\text { in terms of the Parliamentary directive. Hearings } \\
\text { formally started on } 12 \text { September 2018. Final } \\
\text { report was tabled on } 14 \text { March 2019. Questions } \\
\text { were raised around contracts with Visa } \\
\text { Facilitation Services. This matter is ongoing as } \\
\text { of December } 2020 \text {. }\end{array}$ & $\begin{array}{l}\text { - Portfolio } \\
\text { Committee } \\
\text { on Home } \\
\text { Affairs }\end{array}$ & $\begin{array}{l}\text { - Department of } \\
\text { Home Affairs }\end{array}$ \\
\hline $\begin{array}{l}\text { Inquiry into } \\
\text { State Capture } \\
\text { related to } \\
\text { Gupta-owned } \\
\text { mines }\end{array}$ & $\begin{array}{l}\text { In June } 2017, \\
\text { Parliament directed } \\
4 \text { committees } \\
\text { to investigate } \\
\text { state capture. }\end{array}$ & $\begin{array}{l}\text { Though the Committee drafted a term of } \\
\text { reference for the Inquiry, the activities of holding } \\
\text { hearings and consolidating the evidence never } \\
\text { materialised beyond questions being put to then } \\
\text { Minister Zwane. }\end{array}$ & $\begin{array}{l}\text { - Portfolio } \\
\text { Committee } \\
\text { on Mineral } \\
\text { Resources }\end{array}$ & $\begin{array}{l}\text { - Department } \\
\text { of Mineral } \\
\text { Resources }\end{array}$ \\
\hline
\end{tabular}




\begin{tabular}{|c|c|c|c|c|}
\hline $\begin{array}{l}\text { Case Study } \\
\text { in State } \\
\text { Capture }\end{array}$ & Status & Summary Description & $\begin{array}{l}\text { Investigation } \\
\text { Body / } \\
\text { Source of } \\
\text { Evidence }\end{array}$ & $\begin{array}{l}\text { Government } \\
\text { Entity } \\
\text { Implicated }\end{array}$ \\
\hline \multicolumn{5}{|c|}{ Scandals Connected to Jacob Zuma, Guptas, Other Key Networks and ANC Politics } \\
\hline \multicolumn{5}{|c|}{ State Capture of State-Owned Enterprises and Government Departments } \\
\hline \multirow{3}{*}{$\begin{array}{l}\text { Various } \\
\text { investigations } \\
\text { relating to } \\
\text { State Capture } \\
\text { at Eskom }\end{array}$} & 2015 & $\begin{array}{l}\text { In 2015, Dentons produced an interim report } \\
\text { on their investigations into Status of Business } \\
\text { and Challenges at Eskom. Their investigation } \\
\text { was halted. }\end{array}$ & - Eskom & - Eskom \\
\hline & \multirow[t]{2}{*}{2017} & $\begin{array}{l}\text { In 2017, PricewaterhouseCoopers (PwC) was } \\
\text { appointed by National Treasury to investigate } \\
\text { Eskom's Coal Procurement Processes. Damning } \\
\text { findings were made in relation to Gupta-owned } \\
\text { Tegeta mine contracts and poor coal quality. }\end{array}$ & - Eskom & - Eskom \\
\hline & & $\begin{array}{l}\text { G9 was contracted by Eskom to investigate } \\
\text { the Trillian/McKinsey contracts. Interim report } \\
\text { presented to Board of Eskom in August } 2017 . \\
\text { The investigation remained incomplete, and } \\
\text { no report is available in the public domain. } \\
\text { Evidence from the investigation was presented } \\
\text { in the Parliamentary Inquiry into Eskom } \\
\text { State Capture. }\end{array}$ & $\begin{array}{l}\text { - National } \\
\text { Treasury }\end{array}$ & - Eskom \\
\hline $\begin{array}{l}\text { National } \\
\text { Treasury } \\
\text { Fundudzi } \\
\text { reports, } \\
\text { related to } \\
\text { Eskom and } \\
\text { Transnet }(x 3)\end{array}$ & $\begin{array}{l}\text { Final reports } \\
\text { compiled in } \\
\text { November } 2018 \\
\text { and released to } \\
\text { the public shortly } \\
\text { thereafter. }\end{array}$ & $\begin{array}{l}\text { Investigations requested by National Treasury } \\
\text { of alleged corruption at Transnet and Eskom. } \\
\text { The three reports focused on Eskom (general), } \\
\text { the contracts related to Trillian/McKinsey and } \\
\text { Transnet Locomotives. }\end{array}$ & $\begin{array}{l}\text { - National } \\
\text { Treasury } \\
\text { Fundudzi }\end{array}$ & $\begin{array}{l}\text { - Eskom } \\
\text { - Transnet }\end{array}$ \\
\hline \multirow[t]{2}{*}{$\begin{array}{l}\text { Transnet } \\
\text { Locomotive } \\
\text { Contracts }\end{array}$} & \multirow[t]{2}{*}{$\begin{array}{l}\text { Investigations } \\
\text { commenced in } \\
\text { December } 2017 \\
\text { and reports on } \\
\text { findings submitted } \\
\text { during } 2018 .\end{array}$} & $\begin{array}{l}\text { Werksmans Attorneys was appointed in } \\
\text { December } 2017 \text { to undertake an investigation } \\
\text { into the } 1064 \text { Transnet Locomotives } \\
\text { procurement process, however, the investigation } \\
\text { was halted. No report in the public domain. }\end{array}$ & - Werksmans & - Transnet \\
\hline & & $\begin{array}{l}\text { Mncedisi Ndlovu \& Sedumedi (MNS) Attorneys } \\
\text { was then appointed to investigate } 1064 \\
\text { locomotives procurement process. The report } \\
\text { is not in the public domain, but media indicates } \\
\text { that recommendations mirror the Werksmans' } \\
\text { findings and recommends that Molefe face } \\
\text { criminal charges. }\end{array}$ & $\begin{array}{l}\text { - Mncedisi } \\
\text { Ndlovu \& } \\
\text { Sedumedi }\end{array}$ & - Transnet \\
\hline $\begin{array}{l}\text { Inquiry into } \\
\text { State Capture } \\
\text { at Transnet } \\
\text { and Denel }\end{array}$ & $\begin{array}{l}\text { In June } 2017, \\
\text { Parliament directed } \\
4 \text { committees to } \\
\text { investigate state } \\
\text { capture. Committee } \\
\text { hearings were not } \\
\text { completed. }\end{array}$ & $\begin{array}{l}\text { A detailed information booklet was prepared } \\
\text { in relation to Transnet, however, hearings were } \\
\text { not held before the end of term of Parliament. } \\
\text { Following National elections in } 2019 \text {, it } \\
\text { was decided that outstanding Inquiries into } \\
\text { state capture be postponed indefinitely until } \\
\text { conclusion of the Zondo Commission. }\end{array}$ & $\begin{array}{l}\text { - Portfolio } \\
\text { Committee } \\
\text { on Public } \\
\text { Enterprises }\end{array}$ & $\begin{array}{l}\text { - Transnet } \\
\text { - Denel }\end{array}$ \\
\hline
\end{tabular}




\begin{tabular}{|c|c|c|c|c|}
\hline $\begin{array}{l}\text { Case Study } \\
\text { in State } \\
\text { Capture }\end{array}$ & Status & Summary Description & $\begin{array}{l}\text { Investigation } \\
\text { Body / } \\
\text { Source of } \\
\text { Evidence }\end{array}$ & $\begin{array}{l}\text { Government } \\
\text { Entity } \\
\text { Implicated }\end{array}$ \\
\hline \multicolumn{5}{|c|}{ Scandals Connected to Jacob Zuma, Guptas, Other Key Networks and ANC Politics } \\
\hline \multicolumn{5}{|c|}{ Law Enforcement and the Security Cluster } \\
\hline $\begin{array}{l}\text { Enquiry into } \\
\text { Jiba and } \\
\text { Mrwebi's } \\
\text { fitness to } \\
\text { hold office } \\
\text { at NPA }\end{array}$ & $\begin{array}{l}\text { Established in } \\
\text { November } 2018 . \\
\text { Report was issued } \\
\text { in April } 2019 .\end{array}$ & $\begin{array}{l}\text { Presidential Enquiry into the fitness to hold } \\
\text { office of suspended NPA senior advocates } \\
\text { Nomgcobo Jiba and Lawrence Mrwebi. NPA's } \\
\text { deputy head Jiba, and Mrwebi, the head of } \\
\text { the Specialised Commercial Crimes Unit, were } \\
\text { suspended in October } 2018 \text { by President Cyril } \\
\text { Ramaphosa. The Inquiry was headed by retired } \\
\text { Constitutional Court Justice Yvonne Mokgoro. } \\
\text { Jiba and Mrwebi were accused of improper } \\
\text { conduct in their handling of cases involving } \\
\text { former crime intelligence head Richard Mdluli, } \\
\text { as well as former KwaZulu-Natal Hawks boss } \\
\text { Johan Booysen. }\end{array}$ & $\begin{array}{c}\text { - Mokgoro } \\
\text { Enquiry }\end{array}$ & $\begin{array}{l}\text { - } \text { National } \\
\text { Prosecuting } \\
\text { Authority }\end{array}$ \\
\hline $\begin{array}{l}\text { High-Level } \\
\text { Review Panel } \\
\text { on the State } \\
\text { Security } \\
\text { Agency (SSA) }\end{array}$ & $\begin{array}{l}\text { Established in June } \\
2018 \text { and final } \\
\text { report was sent to } \\
\text { the President in } \\
\text { December } 2018 .\end{array}$ & $\begin{array}{l}\text { The High-Level Review Panel into the SSA } \\
\text { was established by President Ramaphosa in } \\
\text { June 2018. The key finding was a serious } \\
\text { politicisation and factionalisation of the } \\
\text { intelligence community over the past decade } \\
\text { or more. This resulted in "an almost complete } \\
\text { disregard for the Constitution, policy, legislation } \\
\text { and other prescripts, and [turned] our civilian } \\
\text { intelligence community into a private resource } \\
\text { to serve the political and personal interests of } \\
\text { particular individuals" (High-Level Review Panel } \\
\text { on the SSA, 2018, p. ii). }\end{array}$ & $\begin{array}{l}\text { - Review } \\
\text { Panel } \\
\text { established } \\
\text { by President } \\
\text { Ramaphosa }\end{array}$ & - SSA \\
\hline $\begin{array}{l}\text { Various court } \\
\text { cases against } \\
\text { persons } \\
\text { within law } \\
\text { enforcement }\end{array}$ & Ongoing. & $\begin{array}{l}\text { Though testimony and evidence have been } \\
\text { presented at the Zondo Commission, it is } \\
\text { understood that no definitive findings will be } \\
\text { made regarding the capture of law enforcement } \\
\text { under the Zuma administration. Since } 2012 \\
\text { onwards, there were several court cases } \\
\text { that were pursued against individuals in law } \\
\text { enforcement, all of which have been either } \\
\text { dismissed or withdrawn. Most noteworthy are } \\
\text { the cases involved, amongst others: Anwa } \\
\text { Dramat and Shadrack Sibiya of the Hawks } \\
\text { (and Robert McBride from Independent Police } \\
\text { Investigative Directorate [IPID]) for allegations } \\
\text { related to the "Zimbabwean rendition" matter; } \\
\text { Johan Booysen for alleged racketeering as part } \\
\text { of "Cato Manor hit squad"; and the various } \\
\text { senior officials accused of being part of the } \\
\text { "rogue" intelligence unit at SARS. Other court } \\
\text { cases that have provided significant evidence } \\
\text { indicating the capture of law enforcement relate } \\
\text { to the irregular appointed allies of the Shadow } \\
\text { State capture network or the irrational removal } \\
\text { of potential opponents holding senior positions } \\
\text { in law enforcement. Example is the irregular } \\
\text { removal of Mxolisi Nxasana as National Director } \\
\text { of Public Prosecutions (NDPP). }\end{array}$ & $\begin{array}{l}\text { - Various } \\
\text { court cases, } \\
\text { proceedings } \\
\text { in Parlia- } \\
\text { ment } \\
\text { - Zondo } \\
\text { Commission }\end{array}$ & $\begin{array}{l}\text { - NPA } \\
\text { - SAPS } \\
\text { - Hawks } \\
\text { - IPID }\end{array}$ \\
\hline
\end{tabular}




\begin{tabular}{|c|c|c|c|c|}
\hline $\begin{array}{l}\text { Case Study } \\
\text { in State } \\
\text { Capture }\end{array}$ & Status & Summary Description & $\begin{array}{l}\text { Investigation } \\
\text { Body / } \\
\text { Source of } \\
\text { Evidence }\end{array}$ & $\begin{array}{l}\text { Government } \\
\text { Entity } \\
\text { Implicated }\end{array}$ \\
\hline \multicolumn{5}{|c|}{ Scandals Connected to Jacob Zuma, Guptas, Other Key Networks and ANC Politics } \\
\hline \multicolumn{5}{|c|}{ Investigations concerning Private Sector } \\
\hline $\begin{array}{l}\text { Budlender } \\
\text { report on } \\
\text { Trillian }\end{array}$ & $\begin{array}{l}\text { Released in } \\
\text { June } 2017 .\end{array}$ & $\begin{array}{l}\text { Trillian Holdings Board appointed Geoff } \\
\text { Budlender SC to undertake investigations into } \\
\text { State Capture allegations at Trillian Capital. } \\
\text { Detailed accounts from whistle-blowers } \\
\text { highlighted how information was withheld by } \\
\text { senior management at Trillian. }\end{array}$ & - Trillion & - Eskom \\
\hline $\begin{array}{l}\text { Collapse of } \\
\text { VBS Mutual } \\
\text { Bank }\end{array}$ & $\begin{array}{l}\text { Investigation } \\
\text { launched in } \\
\text { April } 2018 \text { and } \\
\text { the report was } \\
\text { released in } \\
\text { October } 2018 .\end{array}$ & $\begin{array}{l}\text { Minister of Finance placed VBS under } \\
\text { curatorship with effect from } 11 \text { March 2018. In } \\
\text { April 2018, the Deputy Governor of the South } \\
\text { African Reserve Bank instituted an investigation } \\
\text { into VBS. The outcomes of the investigation } \\
\text { showed blatant fraud and corruption by senior } \\
\text { executives/Board and how they extracted } \\
\text { money from the bank. Municipal funds were } \\
\text { illegally deposited with VBS (senior ANC and } \\
\text { EFF politicians have been implicated). }\end{array}$ & $\begin{array}{l}\text { - SARB } \\
\text { investiga- } \\
\text { tion report } \\
\text { VBS Mutual } \\
\text { Bank - The } \\
\text { Great Bank } \\
\text { Heist }\end{array}$ & $\begin{array}{l}\text { - Several } \\
\text { Provincial and } \\
\text { Municipal } \\
\text { Officials } \\
\text { (Limpopo } \\
\text { Government) } \\
\text { - SOEs } \\
\text { (particularly } \\
\text { PRASA) }\end{array}$ \\
\hline $\begin{array}{l}\text { SA Institute } \\
\text { of Chartered } \\
\text { Accountants' } \\
\text { (SAICA) } \\
\text { investigation } \\
\text { into KPMG }\end{array}$ & $\begin{array}{l}\text { Final report was } \\
\text { handed to SAICA in } \\
\text { December } 2018 .\end{array}$ & $\begin{array}{l}\text { SA Institute of Chartered Accountants (SAICA) } \\
\text { established an Inquiry to investigate state } \\
\text { capture related allegations of misconduct of its } \\
\text { members who worked for KPMG. The Inquiry } \\
\text { chaired by advocate Dumisa Ntsebeza held } \\
\text { public hearings and handed its final report to } \\
\text { SAICA in December 2018. Indications are that } \\
\text { the final report will not be made public until all } \\
\text { investigations and disciplinary hearings have } \\
\text { been finalised. }\end{array}$ & - SAICA & - Guptas \\
\hline Bell Pottinger & $\begin{array}{l}2017 \text { investigation } \\
\text { by PRCA. }\end{array}$ & $\begin{array}{l}\text { In 2016, the Guptas appointed British PR } \\
\text { company, Bell Pottinger, who developed and } \\
\text { promoted a campaign that underpinned the RET } \\
\text { and WMC narratives. In 2017, there was an } \\
\text { independent law firm review by Herbert Smith } \\
\text { Freehills resulting in Bell Pottinger's expulsion } \\
\text { from the Public Relations and Communications } \\
\text { Association (PRCA). }\end{array}$ & $\begin{array}{l}\text { - PRCA } \\
\text { - GuptaLeaks } \\
\text { - Ongoing } \\
\text { research } \\
\text { on disinfor- } \\
\text { mation }\end{array}$ & - Guptas \\
\hline
\end{tabular}

